\title{
Je li euro optimalna valuta za Hrvatsku: ocjena korištenjem teorije optimalnih valutnih područja
}

DOI: https://doi.org/10.15179/pkiep.27.1.1

\section{Mislav Brkić* Ana Šabić*}

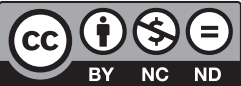

\section{Sažetak}

U ovom se radu primjenom teorije optimalnih valutnih područja analizira je li Hrvatska spremna za uvođenje eura. Ta teorija predlaže nekoliko kriterija koje bi neka država trebala zadovoljiti da bi mogla uspješno funkcionirati u uvjetima zajedničke monetarne politike. Većina kriterija odnosi se na utvrđivanje stupnja ekonomske integracije između pojedine države i monetarne unije, s obzirom na to da snažna ekonomska integriranost implicira manji rizik asimetričnih šokova. Analiza pokazuje da je hrvatsko gospodarstvo trgovinski i financijski vrlo integrirano s europodručjem, poslovni je ciklus usklađen s poslovnim ciklusima najvećih država članica europodručja, a pristupanjem EU-u povećao se i stupanj političke integracije između Hrvatske i ostalih članica. Prema tim kriterijima može se zaključiti da će Hrvatska učinkovito funkcionirati u uvjetima zajedničke monetarne politike. Nasuprot tome, relativno su slaba ostvarenja Hrvatske kada je riječ o kriteriju diversificiranosti gospodarstva. Osim povoljnih ostvarenja Hrvatske prema većini kriterija teorije optimalnih valutnih područja, postoje i drugi važni argumenti u prilog uvođenju eura u Hrvatskoj. Naime, uvođenjem eura nestao bi problem visoke euroiziranosti hrvatskoga gospodarstva, kao i niz drugih rizika i ograničenja koji proizlaze

^ Mislav Brkić, Hrvatska narodna banka, e-mail: mislav.brkic@hnb.hr.

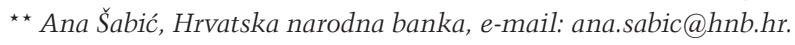


iz tog problema. Uvođenjem eura Hrvatska bi stoga napravila važan korak u smjeru dugoročnog očuvanja makroekonomske stabilnosti.

Ključne riječi: teorija optimalnih valutnih područja, monetarna politika, euro, Hrvatska

JEL klasifikacija: E42, E52, F33, F45

U ovom se radu primjenom teorije optimalnih valutnih područja analizira je li Hrvatska spremna za uvođenje eura. Teorija optimalnih valutnih područja definira određene kriterije koje bi svaka država trebala ispuniti kako bi mogla uspješno sudjelovati u monetarnoj uniji s drugim državama. Ti kriteriji odnose se ponajprije na dostignuti stupanj ekonomske integracije u odnosu na države članice monetarne unije. Naime, ako je neka država snažno trgovinski i financijski integrirana s članicama monetarne unije te ako ima diversificirano gospodarstvo koje je po strukturi slično gospodarstvima drugih članica, njezin će poslovni ciklus vjerojatno biti usklađen s ciklusom ostatka monetarne unije, pa će joj zajednička monetarna politika u pravilu odgovarati. Osim toga, teorija naglašava važnost fleksibilnosti cijena i plaća, mobilnosti rada te fiskalne i političke integracije kao dodatnih mehanizama koji olakšavaju prilagodbu u situacijama kada zajednička monetarna politika ipak nije sasvim primjerena za gospodarstvo države članice.

Dosad je nekoliko autora vrednovalo pripada li Hrvatska istom valutnom području kao i razvijene države zapadne Europe (Šonje i Vrbanc, 2000; Belullo, Šonje i Vrbanc, 2000; Broz, 2008; Kotarac, Kunovac i Ravnik, 2017). U tim je radovima naglasak na mjerenju usklađenosti poslovnih ciklusa Hrvatske i razvijenih europskih država, dok ostali kriteriji nisu detaljnije razmatrani. Doprinos ovoga rada jest u tome što se ocjenjuju ostvarenja Hrvatske prema svim glavnim kriterijima spomenute teorije na osnovi podataka za razdoblje do kraja 2016. godine. S obzirom na to da

${ }^{1}$ Za stajališta iznesena u ovom radu odgovorni su autori i ta stajališta nisu nužno istovjetna službenim stajalištima Hrvatske narodne banke. 
je analizom obuhvaćeno razdoblje nakon pristupanja Europskoj uniji, na ostvarenja prema pojedinim kriterijima utjecale su i strukturne promjene koje su u Hrvatskoj zabilježene kao rezultat članstva u EU-u. Tako je, primjerice, uključivanje Hrvatske na jedinstveno tržište EU-a rezultiralo zamjetljivim jačanjem vanjskotrgovinske razmjene s drugim članicama, pa prema kriteriju trgovinske integracije Hrvatska danas stoji bolje nego u razdoblju prije pristupanja. Nadalje, od ulaska u EU Hrvatska sudjeluje u Europskom semestru - mehanizmu za koordinaciju ekonomskih politika, čime se efektivno povećao stupanj političke integracije s europodručjem. Naposljetku, povećana otvorenost hrvatskog tržišta rada zbog ukidanja prepreka kretanju ljudi pozitivno je utjecala na rezultate Hrvatske prema kriteriju mobilnosti rada.

Analiza pokazuje da je hrvatsko gospodarstvo trgovinski i financijski vrlo integrirano s europodručjem, poslovni je ciklus usklađen s poslovnim ciklusima najvećih država članica europodručja, a pristupanjem EU-u povećao se i stupanj političke integracije između Hrvatske i ostalih članica. Prema tim kriterijima može se zaključiti da će Hrvatska učinkovito funkcionirati u uvjetima zajedničke monetarne politike. Kriterij fleksibilnosti cijena i plaća te kriterij mobilnosti rada također su uvelike zadovoljeni, premda u manjoj mjeri nego ranije spomenuti kriteriji. Nasuprot tome, Hrvatska ostvaruje lošije rezultate kada je riječ o kriteriju diversificiranosti gospodarstva.

Teorija optimalnih valutnih područja ima određene nedostatke zbog kojih ona nije potpuno vjerodostojno mjerilo za ocjenu ekonomske opravdanosti uvođenja eura u Hrvatskoj. Jedan je od nedostataka teorije to što njezini kriteriji često navode na oprečne zaključke o opravdanosti pristupanja države valutnom području. Primjerice, u slučaju Hrvatske teorija ne daje odgovor na pitanje jesu li visoka usklađenost poslovnih ciklusa te snažna trgovinska i financijska integriranost dovoljno jaki argumenti u korist uvođenja eura, pa se lošija ostvarenja kod kriterija diversificiranosti gospodarstva mogu zanemariti. Drugi važan nedostatak teorije jest to što ona zanemaruje valutni rizik koji je državama poput Hrvatske ključan argument u korist pristupanja monetarnoj uniji. Hrvatsko je gospodarstvo visoko euroizirano, 
pri čemu je većina bankovnih kredita i depozita te tri četvrtine javnog duga denominirano u euru ili valutnom klauzulom vezano uz euro. Eventualnim izraženijim slabljenjem tečaja kune, servisiranje dugova vezanih uz euro postalo bi skuplje, što bi smanjilo raspoloživi dohodak domaćih subjekata i tako djelovalo prorecesijski. Deprecijacija tečaja negativno bi djelovala i na bilance banaka jer bi se materijalizirao valutno inducirani kreditni rizik - dio dužnika prestao bi uredno otplaćivati svoje kredite s valutnom klauzulom jer ne bi mogao podmirivati povećane mjesečne anuitete. U takvim okolnostima, stabilan tečaj kune prema euru nametnuo se kao logičan intermedijarni cilj monetarne politike u Hrvatskoj, što sužava prostor za njeno aktivno korištenje u svrhu stabilizacije gospodarstva. Prenošenjem monetarne politike na Europsku središnju banku Hrvatska tako ne bi izgubila mnogo, dok bi istodobno znatno profitirala jer bi uvođenjem eura trajno otklonila najveći dio valutnog rizika, kao i niz drugih s time povezanih rizika i troškova.

Rad je strukturiran na sljedeći način. U drugom poglavlju iznosi se pregled literature o optimalnim valutnim područjima, pri čemu se osim izvorne teorije nude i noviji doprinosi u tom polju, kao i njezini glavni nedostaci. Treće poglavlje bavi se pitanjem je li teorija optimalnih valutnih područja bila relevantno mjerilo kada su čelnici EU-a uspostavljali ekonomsku i monetarnu uniju. U četvrtom poglavlju razmatra se udovoljava li Hrvatska pojedinim kriterijima te se na osnovi toga zaključuje ima li uvođenje eura u Hrvatskoj uporište u teoriji optimalnih valutnih područja. U posljednjem, petom poglavlju, iznose se glavni zaključci rada.

\section{Teorija optimalnih valutnih područja - pregled literature}

Kada govorimo o razvoju literature o optimalnim valutnim područjima, možemo govoriti o različitim fazama u kojima su nastali glavni doprinosi u tom području. Jedan od pristupa vidi razvoj literature u dvije okvirne faze. U prvoj fazi, tijekom 1960-ih i 1970-ih, objavljeni su teorijski radovi koji su definirali ključne kriterije za određivanje granica valutnih područja, 
a u drugoj fazi, nakon 1970-ih, literatura se usredotočuje na empirijsko proučavanje koristi i troškova sudjelovanja u valutnom području (Horwath i Komarek, 2002). ${ }^{2}$

\subsection{Osnovne postavke teorije optimalnih valutnih područja}

Svrha teorije optimalnih valutnih područja bila je razviti skup kriterija koji će državama dati odgovor na pitanje isplati li im se trajno fiksirati devizne tečajeve ili ne. ${ }^{3}$ Teorija je zasnovana na radovima Mundella (1961), McKinnona (1963) i Kenena (1969), a doprinos su dali i Friedman (1953), Ingram (1962) i Mintz (1970). U tim se radovima spominje niz kriterija koji određuju hoće li države odnosno regije činiti optimalna valutna područja, odnosno hoće li nekoj državi pogodovati sudjelovanje u monetarnoj uniji s drugim državama. Kriteriji koje predlažu autori ove teorije su: visok stupanj trgovinske i financijske integracije, usklađenost poslovnih ciklusa i ekonomskih šokova, mobilnost rada, fleksibilnost cijena i plaća, diversificiranost proizvodnje te fiskalna i politička integracija. Iscrpan pregled literature o teoriji optimalnih valutnih područja donose Belullo i sur. (2000), Mongelli (2002) i Broz (2005). U nastavku je ukratko pojašnjena ekonomska argumentacija za glavne kriterije spomenute teorije.

Visok stupanj trgovinske integracije umanjuje važnost monetarne samostalnosti. McKinnon (1963) smatra da trgovinska integracija ima presudnu ulogu pri definiranju optimalnih valutnih područja. On tvrdi da malim otvorenim gospodarstvima odgovara uspostavljanje monetarnih unija s najvažnijim vanjskotrgovinskim partnerima. Naime, s obzirom na to da je u takvim gospodarstvima udio međunarodno razmjenjivih dobara u potrošačkoj košarici vrlo visok, fluktuacije deviznog tečaja preko cijena razmjenjivih dobara brzo se prenose na domaću inflaciju, a to umanjuje učinkovitost deviznog tečaja kao poluge ekonomske politike. Suprotno

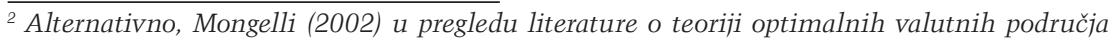
navodi četiri faze obiliežene važnim doprinosima: pionirska faza (od 1960. do ranih 1970-ih), faza usklađivanja (tijekom 1970-ih), faza ponovnog ispitivanja (od 1980. do ranih 1990-ih) i empirijska faza (od ranih 1990-ih).

${ }^{3}$ Radovi na kojima se zasniva teorija optimalnih valutnih područja zapravo sadržavaju rasprave o izboru između režima fleksibilnog i fiksnog tečaja, gdje je monetarna unija krajnji oblik režima fiksnoga deviznog tečaja.
} 
tome, velikim gospodarstvima više odgovara zadržavanje monetarne neovisnosti. Velika gospodarstva u pravilu su relativno zatvorena te stoga imaju znatno niži udio međunarodno razmjenjivih dobara u potrošačkoj košarici. U takvim uvjetima, devizni tečaj može se aktivno koristiti u svrhu izglađivanja poslovnog ciklusa.

Financijska integracija može pridonijeti stabilnosti monetarne unije. Ingram (1962) smatra da financijska integracija može smanjiti potrebu za prilagodbom nominalnog tečaja jer tokovi kapitala među državama članicama mogu pomoći u smanjenju privremenih neravnoteža. Primjerice, ako među državama postoje snažne financijske veze, država koja je pogođena negativnim šokom može se zadužiti kod drugih država i tako premostiti privremeni jaz u financiranju. Takvi financijski tokovi jamče otpornost monetarnoj uniji i pridonose konvergenciji troškova zaduživanja država članica.

\section{Visoka razina usklađenosti poslovnih ciklusa i ekonomskih šokova} olakšava vođenje zajedničke monetarne politike. Ako među državama članicama monetarne unije postoji visoka razina usklađenosti poslovnih ciklusa - što implicitno znači da su države izložene sličnim šokovima agregatne ponude i potražnje i da je transmisija tih šokova približno simetrična - jedinstvena monetarna politika podjednako će odgovarati svim članicama. Neki autori smatraju da je kriterij usklađenosti poslovnih ciklusa i ekonomskih šokova kompozitni kriterij, jer da bi on bio zadovoljen, potrebno je prethodno zadovoljiti barem dio ostalih kriterija, i to ponajprije kriterij trgovinske integracije (Mongelli, 2002).

Ako postoji visoka mobilnost rada, monetarna unija lakše će se prilagođavati asimetričnim šokovima jer će radnici migrirati iz država ili regija pogođenih recesijom u države ili regije koje se nalaze u fazi ekspanzije. Prema Mundellu (1961), mobilnost rada ključna je odrednica optimalnih valutnih područja. Što je veća mobilnost rada, manja je potreba za prilagodbom deviznog tečaja i plaća, pa je jednostavnije provoditi zajedničku monetarnu politiku. U skladu s time, svaka regija unutar koje postoji visoka mobilnost rada ima obilježje optimalnoga valutnog područja. 
Fleksibilnost cijena i plaća također se ubraja među kriterije teorije optimalnih valutnih područja. Friedman (1953) tvrdi da bi države članice monetarne unije trebale posjedovati dostatnu razinu fleksibilnosti cijena i plaća kako bi u uvjetima zajedničke monetarne politike mogle amortizirati idiosinkratske šokove, dakle one šokove koji pogađaju pojedinačne države. Ako postoji mogućnost prilagodbe nominalnih cijena i plaća, države članice koje su pogođene šokom moći će te šokove apsorbirati, a da se pritom ne suoče s visokim troškovima u obliku porasta nezaposlenosti i pada dohotka. S druge strane, ako je rigidnost cijena i plaća visoka, troškovi prilagodbe unutar monetarne unije mogli bi biti znatni, što upućuje na potencijalnu korist od zadržavanja vlastite valute.

Diversificirana struktura gospodarstva umanjuje važnost deviznog tečaja kao instrumenta makroekonomske prilagodbe. Tu tezu prvi je iznio Kenen (1969). On smatra da diversificirana struktura gospodarstva ublažava agregatni utjecaj šokova koji pogađaju pojedine grane industrije. U takvim je uvjetima manja vjerojatnost da će poremećaji u jednom sektoru imati presudan utjecaj na kretanje ukupne gospodarske aktivnosti, pa se time umanjuje i važnost deviznog tečaja kao instrumenta za amortizaciju šokova.

Naposljetku, neki su autori istaknuli fiskalnu i političku integraciju kao nužne preduvjete za dugoročnu održivost monetarne unije. Kenen (1969) tako navodi da fiskalna integracija olakšava funkcioniranje monetarne unije jer može smanjiti potrebu za prilagodbama putem nominalnih tečajeva. Naime, ako je članica monetarne unije pogođena asimetričnim šokom, ona će taj šok moći lakše prebroditi ako unija posjeduje odgovarajući mehanizam fiskalnih transfera koji se odobravaju državama zahvaćenima krizom. S druge strane, Mintz (1970) smatra da je politička integracija, odnosno politička volja za integracijom najvažniji preduvjet koji treba ispuniti prije uspostavljanja zajedničke valute. Razlog je u tome što politička volja za integracijom potiče države na poštivanje zajedničkih pravila i koordinaciju ekonomskih politika te dovodi do jačanja institucionalnih veza. Ova dva kriterija izravno su povezana - visok stupanj političke integracije, odnosno politička unija koja podrazumijeva spremnost na dijeljenje rizika 
izravan je i nužan preduvjet izgradnje fiskalne unije u smislu postojanja nadnacionalnog sustava fiskalnih transfera koji se aktivira u slučaju asimetričnog šoka.

\subsection{Novi pravci razvoja teorije optimalnih valutnih područja}

Iako se zanimanje istraživača $\mathrm{s}$ vremenom preusmjerilo $\mathrm{s}$ teorijskih radova na empirijske studije, teorija optimalnih valutnih područja tijekom godina ipak je doživjela nadogradnju, za što su ponajviše zaslužni Frankel i Rose (1998). Oni su tvrdili da postoji određena endogenost kriterija teorije optimalnih valutnih područja, koja se ogleda u tome što članstvo u monetarnoj uniji može pomoći državi da zadovolji kriterije iako ih prije pristupanja nije zadovoljavala. Naime, varijable poput ekonomske integracije (stupanj trgovinske otvorenosti) i korelacije dohotka (usklađenost poslovnih ciklusa) nisu nepovratno fiksirane, nego se tijekom vremena mijenjaju. Primjerice, pristupanjem neke države monetarnoj uniji vanjskotrgovinska razmjena te države i ostatka monetarne unije može se intenzivirati, a to ujedno može povećati usklađenost poslovnih ciklusa između te države i ostatka unije. Postojanje endogenosti jedan je od glavnih razloga zašto se teorija optimalnih valutnih područja ne može smatrati potpuno pouzdanim okvirom za procjenu ekonomske opravdanosti pristupanja monetarnoj uniji. De Grauwe i Mongelli (2005) potvrdili su relevantnost endogenosti u slučaju europodručja. Naime, kada je riječ o kriteriju financijske integracije, autori primjećuju da su se novčana tržišta u europodručju integrirala gotovo trenutačno s formiranjem monetarne unije, a visok stupanj integracije dostignut je i na tržištu javnog duga, što se ogledalo u izjednačavanju prinosa na obveznice fundamentalno različitih država članica. Pojedina empirijska istraživanja pokazuju da je uvođenje zajedničke valute dovelo i do porasta usklađenosti poslovnih ciklusa među državama članicama (Darvas i Szapary, 2008; Furceri i Karras, 2008; Gogas, 2013).

Osim teorije endogenosti integracije, u literaturi se može naći i potpuno suprotna teorija - teorija specijalizacije. Primjerice, Krugman (1993) ističe da trgovinska liberalizacija potiče specijalizaciju u skladu sa specifičnim 
komparativnim prednostima pojedinih država, što može izazvati divergenciju poslovnih ciklusa, umjesto konvergencije koju predviđa teorija endogenosti. Uzimajući u obzir stupanj specijalizacije američkih saveznih država, Bayoumi i Eichengreen (1992) ističu da bi dovršetak projekta jedinstvenog tržišta u EU-u mogao potaknuti države članice na proizvodnu specijalizaciju, što bi buduću monetarnu uniju moglo učiniti ranjivom na asimetrične šokove. Fidrmuc (2004) tvrdi da odgovor na pitanje hoće li prevladati endogenost ili specijalizacija ovisi ponajprije o tome hoće li se među državama intenzivnije razvijati unutarindustrijska ili međuindustrijska trgovina. Naime, autor na osnovi podataka za države OECD-a pronalazi da sinkroniziranost ciklusa među državama raste kako se povećava vanjskotrgovinska razmjena, ali uz uvjet da se unutarindustrijska razmjena povećava relativno snažnije od međuindustrijske.

\subsection{Slabosti teorije optimalnih valutnih područja}

Teorija optimalnih valutnih područja ima određene slabosti zbog kojih nije potpuno pouzdana osnova za ocjenjivanje opravdanosti pristupanja neke države zajedničkom valutnom području. Tavlas (1994) teoriji zamjera to što donošenje odluke često nije moguće jer različiti kriteriji mogu upućivati na oprečne zaključke. Može se dogoditi da jedna skupina kriterija upućuje na to da država treba imati fiksan tečaj (odnosno pristupiti monetarnoj uniji), dok druga skupina kriterija istodobno upućuje na to da bi fleksibilan tečaj (monetarna neovisnost) bio primjereniji. Primjerice, ako neka država ostvaruje intenzivne trgovinske odnose s državama partnerima, prema kriterijima trgovinske otvorenosti i usklađenosti ciklusa ta bi država bila dobar kandidat za monetarnu uniju s državama partnerima. Međutim, ako je prekogranična mobilnost rada između te države i njezinih partnera niska, prema kriteriju mobilnosti rada toj bi državi bolje odgovarala monetarna autonomija. Tavlas (1994) kao drugi važan nedostatak teorije optimalnih valutnih područja ističe njezinu nedosljednost, koja se najbolje očituje u koliziji između kriterija trgovinske integracije i kriterija diversificiranosti proizvodnje. Ovaj autor podsjeća da su mala gospodarstva u pravilu otvorenija, pa bi prema kriteriju trgovinske integracije tim 
gospodarstvima odgovarao fiksan devizni tečaj prema valutama ključnih vanjskotrgovinskih partnera (odnosno pristupanje monetarnoj uniji). Istodobno, mala gospodarstva uglavnom su slabo diversificirana, što bi, uzimajući u obzir kriterij diversificiranosti proizvodnje, značilo da je za njih primjereniji fleksibilan tečajni režim (monetarna neovisnost). Velika gospodarstva u pravilu su više diversificirana, ali su zato manje otvorena, pa i u njihovu slučaju ova dva kriterija upućuju na oprečne zaključke.

Mongelli (2008) smatra da je dodatna manjkavost teorije optimalnih valutnih područja to što njezini začetnici nisu predvidjeli rastuću važnost usluga u gospodarstvu. Naime, kada se države vrednuju prema kriteriju diversificiranosti gospodarstva, naglasak je na analizi strukture industrije, dok su iz razmatranja izuzete uslužne djelatnosti. S obzirom na to da je uslužni sektor u pravilu više diversificiran od proizvodnog sektora, države članice EU-a doimale bi se boljim kandidatima za monetarnu uniju kad bi se analizirala diversificiranost ukupnoga gospodarstva, dakle uključujući uslužni sektor.

Nadalje, teorija optimalnih valutnih područja ne sadrži kriterij koji bi utvrdio postoje li u monetarnoj uniji mehanizmi za suzbijanje makroekonomskih neravnoteža i ublažavanje negativne povratne sprege između bilanci banaka i javnih financija. Tijekom recentne krize u europodručju pokazalo se da su upravo takvi mehanizmi ključni za dugoročnu stabilnost, a time i za optimalnost monetarne unije. Naime, nedavna povijest europodručja pokazala je da ako pojedine države članice nekontrolirano gomilaju makroekonomske neravnoteže, u jednom trenutku te će države biti prisiljene naglo ispraviti prekomjerne neravnoteže, što posredno može izazvati znatne troškove i za ostale, fundamentalno zdrave članice. Manjkavost (tradicionalne) teorije optimalnih valutnih područja ogleda se i u tome što praktički izostavlja specifična pitanja povezana s bankarskim sektorom i njegovim potencijalno štetnim utjecajem na državne financije. Krugman (2013) uspoređuje situaciju u europodručju s onom u SAD-u te ističe kako postojanje zajedničkog jamstva za bankovne depozite može imati ključnu ulogu za stabilnost monetarne unije. To se posebice očitovalo tijekom recentne financijske krize. Dok se za obveze banaka u SAD-u 
jamči na federalnoj razini i eventualni bailout nije opterećenje za proračun pojedine savezne države, u europodručju se spašavanje banaka provodilo na teret državnih proračuna, što je u nekim državama, poput Irske, pridonijelo snažnom rastu javnog duga. ${ }^{4}$

Teorija optimalnih valutnih područja precjenjuje učinkovitost monetarne i tečajne politike u malim otvorenim gospodarstvima. Naime, navedena teorija potječe iz 1960-ih godina, kada je prekogranična mobilnost kapitala bila ograničena, što je središnjim bankama jamčilo visok stupanj autonomije u provođenju monetarne politike. Rey (2015) smatra da u današnje vrijeme, u okružju intenzivnih međunarodnih tokova kapitala, mala država u praksi ne može voditi aktivnu monetarnu politiku, neovisno o tome primjenjuje li režim fleksibilnoga ili fiksnoga deviznog tečaja. Jedini način da država zadrži monetarnu autonomiju jest da se primjenom makroprudencijalnih mjera i kapitalnih kontrola izolira od utjecaja monetarnih politika ključnih svjetskih gospodarstava.

Naposljetku, izvorna teorija zanemaruje valutni rizik koji nekim državama, poglavito državama s tržištima u nastajanju, može biti važan argument u korist pristupanja zajedničkom valutnom području. Valutni rizik proizlazi iz valutne neusklađenosti u bilancama gospodarskih subjekata. Ako neki subjekt ima dug u stranoj valuti, a ne posjeduje imovinu u stranoj valuti niti ostvaruje prihode u njoj, u slučaju deprecijacije domaće valute njegov će se financijski položaj pogoršati. Valutni rizik osobito je velik problem u državama s tržištima u nastajanju, u kojima je zaduživanje u stranoj valuti vrlo rašireno. Takva praksa djelomično proizlazi iz toga što međunarodni investitori njihove valute ne smatraju vjerodostojnima, pa je izdavanje duga u konvertibilnim stranim valutama - poput američkog dolara - često jedini način da te države privuku kapital iz inozemstva (Mishkin, 1997; Eichengreen, Hausmann i Panizza, 2003). Problem zaduživanja u stranoj valuti povezan je i s time što u mnogim državama domaća valuta često ne

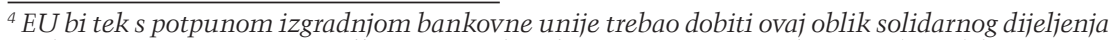
rizika; 2015. je iznesen prijedlog o europskoj shemi za osiguranje depozita (EDIS) kao trećem i posljednjem stupu bankovne unije. Pregovori između država članica i dalje traju, a relativno spor napredak prema konačnom rješenju odražava različite stavove država članica prema ovoj mjeri. Prva dva stupa bankovne unije odnose se na jedinstveni nadzorni mehanizam i jedinstveni sanacijski mehanizam, koji su s radom započeli 2014. odnosno 2016. godine. 
obavlja funkciju sredstva štednje. ${ }^{5}$ Naime, u slabije razvijenim državama građani često nemaju dovoljno povjerenja u nacionalnu valutu pa svoju štednju preferiraju držati u obliku deviznih depozita. Visok udio deviznih depozita u ukupnim izvorima financiranja banaka nadalje potiče banke da kredite također indeksiraju uz stranu valutu kako bi zatvorile svoje devizne pozicije. Iako se plasiranjem indeksiranih kredita banke prividno štite od valutnog rizika, one zapravo taj rizik samo transformiraju u valutno inducirani kreditni rizik koji se može materijalizirati u slučaju nepovoljnih tečajnih kretanja. Radi se o tome da u slučaju slabljenja domaće valute dio dužnika ne bi bio sposoban podmirivati povećane anuitete svojih kredita s valutnom klauzulom, što bi bankama prouzročilo kreditne gubitke. Sklonost građana da štede u stranoj valuti nemoguće je potpuno iskorijeniti, pa je samim time i problem kreditiranja u stranoj valuti najčešće trajnog karaktera. Stupanj dolarizacije (euroizacije) moguće je smanjiti administrativnim putem, primjerice tako da se zabrane devizni depoziti, odnosno nametne konverzija deviznih depozita u domaću valutu. Međutim, iskustva nekoliko latinoameričkih država pokazala su da takve mjere mogu imati štetan učinak na financijski sustav i ukupno gospodarstvo jer potiču bijeg kapitala i guše financijsko posredovanje (Ize i Levy Yeyati, 2003).

Prisutnost valutnog i valutno induciranog kreditnog rizika može imati značajne implikacije na ukupan odnos koristi i troškova pristupanja monetarnoj uniji. U državama u kojima su ti rizici veliko opterećenje, potencijalna korist od njihovog uklanjanja može biti važan argument za pristupanje monetarnoj uniji. Osim toga, prisutnost tih rizika smanjuje stupnjeve slobode monetarne politike, pa ulaskom u monetarnu uniju takve države u biti ne gube važan instrument ekonomske politike. Naime, kako ističu Belullo i sur. (2000), ako postoji valutna supstitucija, odnosno ako se domaći sektori zadužuju u stranoj valuti, monetarna politika ne može se aktivno koristiti u svrhu amortizacije šokova jer u takvim okolnostima

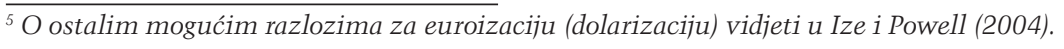


intermedijarni cilj središnje banke postaje očuvanje stabilnosti tečaja. ${ }^{6}$ Suprotno tome, u državama u kojima zaduživanje u stranoj valuti nije toliko prisutno, stabilnost tečaja nema jednaku stratešku važnost pa je i manevarski prostor za monetarnu politiku mnogo veći. To se posebice odnosi na velike razvijene države poput SAD-a, koje u razdobljima kriza mogu provoditi izrazito ekspanzivnu monetarnu politiku bez bojazni da će eventualna deprecijacija tečaja naštetiti gospodarstvu (Mishkin, 1997). Iz toga proizlazi da visokoeuroizirane države poput Hrvatske odricanjem od samostalne monetarne politike gube mnogo manje od država koje nisu euroizirane i koje zahvaljujući tome mogu aktivnije koristiti monetarnu politiku. Ova pitanja teorija optimalnih valutnih područja potpuno zanemaruje.

\section{Relevantnost teorije optimalnih} valutnih područja za EMU

Kada su čelnici tadašnje Europske zajednice raspravljali o mogućnosti uspostavljanja monetarne unije, motivi su bili ponajprije političke naravi, uz želju da se iskoriste ekonomske prednosti zajedničke valute. Stvaranjem monetarne unije željela se eliminirati neizvjesnost vezana uz kretanja nominalnih deviznih tečajeva te tako u potpunosti iskoristiti potencijal jedinstvenog tržišta. Činjenica da prema teoriji optimalnih valutnih područja nekoliko država članica nije bilo spremno za pristupanje monetarnoj uniji tada nije zabrinjavala europske čelnike. Uzimajući u obzir financijsku krizu koja je 2010. pogodila monetarnu uniju, jasno je da je izvorni EMU patio od određenih slabosti.

\footnotetext{
${ }^{6}$ Hausmann, Panizza i Stein (2001) utvrđuju da države s tržištima u nastajanju prosječno održavaju veće količine međunarodnih pričuva i češće interveniraju na deviznom tržištu od razvijenih država upravo zato jer žele izbjeći znatniju deprecijaciju tečaja koja bi otežala servisiranje duga u stranoj valuti.
} 


\subsection{Uloga teorije optimalnih valutnih područja u procesu uspostavljanja EMU-a}

Države članice Europske zajednice nastojale su održavati devizne tečajeve svojih nacionalnih valuta relativno stabilnima dugi niz godina, pa je uvođenje zajedničke valute bio logičan sljedeći korak. To je zapravo bio jedini način da se postigne vjerodostojna valutna stabilnost, jer su svi prethodni valutni aranžmani naposljetku ispali neučinkoviti. Razlog je bio u tome što je u tim aranžmanima jedna država - Njemačka - imala dominantnu ulogu, što joj je omogućavalo da vodi monetarnu politiku u skladu s vlastitim potrebama, a sve ostale države morale su se usklađivati s Njemačkom kako bi očuvale stabilnost svojih valuta u odnosu na njemačku marku. Monetarna politika njemačke središnje banke dakako nije uvijek odgovarala ostalim državama članicama. Kao posljedica toga, valute slabijih država često su bile izložene špekulativnim napadima, koji su nerijetko rezultirali devalvacijama. Uvođenjem zajedničke valute spomenuti izvori problema su uklonjeni: rizik špekulativnih napada na nacionalne valute u potpunosti je uklonjen, a monetarna dominacija Njemačke je u velikoj mjeri smanjena jer su sve države članice dobile jednako pravo glasa pri oblikovanju zajedničke monetarne politike.?

Poslijeratni svjetski monetarni sustav dogovoren na konferenciji u Bretton Woodsu 1944. godine temeljio se na zlatno-dolarskom standardu, koji je podrazumijevao konvertibilnost američkog dolara u zlato po fiksnom paritetu, a ostale države bile su dužne održavati tečajeve svojih valuta striktno vezanima uz američki dolar (Bordo, 1993). Vezivanjem uz američki dolar kao zajedničko sidro, nacionalne valute europskih država

\footnotetext{
${ }^{7}$ Premda guverneri država članica europodručja ravnopravno sudjeluju u donošenju odluka Europske središnje banke, Njemačka je kao najveće gospodarstvo ipak zadržala dio svoje monetarne dominacije. Cak i prije samog uspostavljanja EMU-a Niemačka se pobrinula da zajednička monetarna politika ne odstupa od njenih interesa. Naime, u pregovorima o formiranju EMU-a početkom 1990-ih Niemačka je inzistirala na tome da buduća Europska središnja banka (ESB) - po uzoru na njemački Bundesbank - bude potpuno usredotočena na očuvanje stabilnosti cijena. Nadalie, s obzirom na visok udio Njemačke u ukupnom gospodarstvu europodručja, ESB pri vođenju monetarne politike u praksi mora veću pozornost posvećivati makroekonomskim kretanjima u Njemačkoj nego kretanjima u manjim državama članicama. Naposljetku, Niemačka je, kao jedna od osovina EU-a, u razdoblju nakon svjetske financijske krize imala vodeću ulogu u pregovorima o reformi institucionalnog uređenja monetarne unije.
} 
također su međusobno bile usko vezane. ${ }^{8}$ Sporazum iz Bretton Woodsa prestao je vrijediti u kolovozu 1971., kada je američka vlada odlučila obustaviti konvertibilnost dolara u zlato. Krajem iste godine dogovoreno je da će američki dolar devalvirati, nekoliko drugih valuta revalvirati, a uveden je raspon fluktuacija tečajeva ostalih valuta oko američkog dolara od $\pm 2,25$ posto. Takav aranžman nije odgovarao Europskoj zajednici jer se maksimalan raspon fluktuacija među valutama članica time znatno povećao. ${ }^{9}$

Kako bi izbjegle valutnu nestabilnost nakon raspada zlatno-dolarskog standarda, početkom 1972. države članice odlučile su ograničiti maksimalni raspon fluktuacija među nacionalnim valutama, ali je taj aranžman pod utjecajem vanjskih šokova ubrzo raskinut. Premda je taj pokušaj završio neuspjehom, članice su nastavile težiti valutnoj stabilnosti, pa 1979. osnivaju Europski monetarni sustav. Važan element tog sustava bila je europska valutna jedinica ECU (European Currency Unit), koju je činila košarica valuta svih država članica. Nacionalne valute bile su uključene u tečajni mehanizam (Exchange Rate Mechanism, ERM), a države članice bile su dužne u okviru tog mehanizma devizne tečajeve održavati stabilnima u odnosu na ECU.

Tečajni mehanizam bio je tijekom 1992. i 1993. izložen snažnim pritiscima kada su se valute nekoliko država sudionica tog mehanizma našle na udaru špekulativnih napada (Buiter, Corsetti i Pesenti, 1998). Kao posljedica tih napada, talijanska lira i funta sterlinga napustile su tečajni mehanizam, a nekoliko država odlučilo je devalvirati svoje valute. Kako bi se smanjio rizik špekulativnih napada u budućnosti, standardni raspon fluktuacija u ERM-u proširen je na \pm 15 posto 1993. godine. U literaturi postoji suglasje oko toga da je jedan od glavnih uzročnika krize ERM-a bilo ujedinjenje Zapadne i Istočne Njemačke u listopadu 1990. godine (Higgins, 1993;

\footnotetext{
${ }_{8}^{8}$ Treba napomenuti da su revizije središnjih pariteta nacionalnih valuta u odnosu na dolar ipak bile moguće. Najpoznatiji slučajevi prilagodbi središnjih pariteta dogodili su se krajem 1960-ih, kada je zbog pritisaka na deviznom tržištu njemačka marka morala revalvirati, dok je francuski franak devalvirao pod utjecajem domaćih političkih previranja (Garber, 1993).

${ }^{9}$ Primjerice, kad bi tečaj talijanske lire u odnosu na američki dolar porastao s donje granice od $-2,25$ posto na gornju granicu od $+2,25$ posto, a tečaj njemačke marke u odnosu na američki dolar istodobno se snizio s gornje od $+2,25$ posto na donju granicu od $-2,25$ posto, talijanska bi lira prema njemačkoj marci deprecirala za ukupno 9 posto.
} 
Buiter i sur., 1998; Eichengreen, 2000). Naime, snažno povećanje javne potrošnje u svrhu financiranja obnove istočnih regija dovelo je do jačanja inflacijskih pritisaka u Njemačkoj, na što je središnja banka reagirala stezanjem monetarne politike. Zbog potrebe održavanja stabilnog tečaja prema njemačkoj marci ostale države članice također su bile prisiljene pooštriti monetarnu politiku iako im to nije odgovaralo s obzirom na fazu poslovnog ciklusa. Divergentni stavovi država članica o poželjnom usmjerenju nacionalnih monetarnih politika bili su povod za špekulativne napade na valute država sudionica tečajnog mehanizma, čime su špekulanti pokušali natjerati članice na napuštanje tečajnog mehanizma i devalvaciju valuta.

Učinkovito funkcioniranje Europskoga monetarnog sustava tijekom 1980-ih ohrabrilo je članice da poduzmu daljnje korake u smjeru monetarnog ujedinjenja. U tom kontekstu, osnovan je odbor pod vodstvom Jacquesa Delorsa, tadašnjeg predsjednika Europske komisije, s mandatom da osmisli sljedeće korake za uspostavljanje ekonomske i monetarne unije. Svoje prijedloge odbor je iznio u tzv. Delorsovu izvješću, koje je kasnije bilo temelj za Ugovor iz Maastrichta. Delorsovo izvješće (Committee for the Study of Economic and Monetary Union, 1989) nije odgovorilo na pitanje je li tadašnja Europska zajednica optimalno valutno područje. Odluka o stvaranju ekonomske i monetarne unije bila je politička odluka, a Delorsov odbor osnovan je s mandatom da pripremi provedbu te odluke. U izvješću se kao ključni argumenti u korist monetarne unije navode uklanjanje rizika pretjerane kolebljivosti deviznih tečajeva, smanjenje transakcijskih troškova te povećanje otpornosti Europske zajednice na vanjske šokove. Premda se izvješće ne referira na teoriju optimalnih valutnih područja, pojedini zaključci iz Delorsova izvješća ipak se mogu povezati s njezinim kriterijima. Primjerice, u izvješću se naglašava da će u uvjetima zajedničke monetarne politike, koordinacija u području drugih ekonomskih politika, posebice fiskalne, biti ključna za postizanje održivog rasta, stabilnosti cijena i očuvanje vanjske ravnoteže gospodarstava. Također, u Delorsovu izvješću spominju se fleksibilnost plaća i mobilnost rada kao dodatni važni činitelji uspiešnog funkcioniranja monetarne unije. Autori ovog izvješća predvidjeli su mogućnost pojave makroekonomskih neravnoteža unutar monetarne 
unije, pri čemu su pretpostavili da bi te neravnoteže mogle proizaći iz neusklađene dinamike troškova rada ili asimetričnih reakcija članica na vanjske šokove. Međutim, Delorsov odbor nije razlikovao države članice u smislu njihove spremnosti za ulazak u monetarnu uniju, nego se držao pretpostavke da će monetarna unija podjednako koristiti svim državama.

U studiji o mogućim ekonomskim učincima monetarne unije, Europska komisija (1990) je procijenila da su potencijalne koristi od monetarnog ujedinjenja država članica mnogo veće nego što bi se moglo zaključiti na temelju teorije optimalnih valutnih područja. Pritom se napominje da je monetarna unija između država članica nužna ako se želi sačuvati stabilnost deviznih tečajeva nakon pune liberalizacije kapitalnih transakcija. U glavne koristi monetarne unije ubrojene su mikroekonomske uštede zbog eliminacije valutnog rizika i smanjenja transakcijskih troškova, ali i pozitivni makroekonomski učinci u obliku niže agregatne inflacije i manje kolebljivosti gospodarskog rasta. U studiji se pojašnjava da bi smanjenje agregatne inflacije trebalo proizaći iz toga što će zajednička monetarna politika biti zasnovana na snažnoj disciplini po uzoru na članice poput Njemačke koje su prije osnivanja EMU-a bile najuspješnije u očuvanju stabilnosti cijena. Vjerodostojnost zajedničke monetarne politike nadalje bi trebala pridonijeti suzbijanju inflacijskih očekivanja u onim državama koje su prije pristupanja monetarnoj uniji bile sklone visokim stopama inflacije. U dokumentu je ispravno predviđeno da će ukidanje premije za valutni rizik i smanjenje premije za rizik inflacije zbog formiranja monetarne unije omogućiti povoljnije uvjete zaduživanja rubnim državama članicama.

Kada je riječ o negativnim aspektima monetarne unije, Europska komisija (1990) navodi da će gubitak monetarne i tečajne politike kao instrumenata makroekonomske prilagodbe biti ključan trošak iz perspektive članica. Međutim, pritom je istaknuto da taj trošak ne bi trebao biti presudan s obzirom na to da su se države članice u okviru EMS-a već ionako odrekle nominalnog tečaja kao instrumenta stabilizacije. U studiji je također napomenuto da će državama na raspolaganju ostati fiskalna politika i politika dohodaka, kojima će moći apsorbirati asimetrične šokove tijekom sudjelovanja u monetarnoj uniji. 
$\mathrm{Na}$ kraju možemo zaključiti da se ekonomskoj integraciji i osobito uvođenju zajedničke valute pristupilo kao procesu korisnom za poticanje političke integracije i očuvanje (političke) stabilnosti. Krugman (2013) sažima očekivanja iz vremena uspostavljanja EMU-a i napominje kako se tada očekivalo da će dva važna obilježja - mobilnost faktora proizvodnje, posebno mobilnost rada, i fiskalna integracija - iako niskog stupnja u vrijeme nastanka EMU-a, omogućiti prilagodbe asimetričnim šokovima u budućnosti. Vjerovalo se da će članice voditi razborite fiskalne politike, među ostalim i dosljednom provedbom pravila, čime bi se smanjila učestalost pojave asimetričnih šokova. S druge strane, vjerovalo se da će članice provesti potrebne strukturne reforme koje će omogućiti veću fleksibilnost tržišta rada, a i plaća, što bi onda pomoglo u slučaju da se asimetrični šokovi ipak pojave.

\subsection{Je li europodručje optimalno valutno područje?}

Teorija optimalnih valutnih područja može pomoći u prepoznavanju manjkavosti izvornog europodručja (EMU-12) koje su gotovo dovele do njegova raspada. U razdoblju nakon uvođenja eura nekoliko država članica doživjelo je pretjeranu gospodarsku ekspanziju praćenu rastom štetnih makroekonomskih neravnoteža. Nakon izbijanja svjetske krize krajem 2008. te su države bile prisiljene korigirati prisutne neravnoteže te je u njima nastupila duboka recesija, a potom i dužnička kriza, koja je dovela u pitanje održivost eura kao zajedničke valute. U nastavku se analizira je li EMU-12 bio optimalno valutno područje. Pritom je poseban naglasak na kriterijima koji su važni za razumijevanje korijena duboke dužničke krize koja je 2010. pogodila rubne članice europodručja. Nakon toga se opisuju reforme koje su provedene tijekom i nakon krize, a koje bi trebale smanjiti podložnost europodručja financijskim i ekonomskim krizama u budućnosti. 
3.2.1. Rezultati izvornog EMU-12 prema teoriji optimalnih valutnih područja

Kriterij trgovinske integracije upućuje na to da postoji snažna ekonomska argumentacija za postojanje monetarne unije europskih država. Naime, obujam vanjskotrgovinske razmjene između država članica izvornog EMU-a vrlo je visok, a to, prema teoriji optimalnih valutnih područja, može biti valjan motiv za uspostavljanje monetarne unije i važan činitelj njezine učinkovitosti. U godini osnivanja EMU-a razmjena s ostatkom monetarne unije činila je više od polovine ukupne robne razmjene za većinu izvornih država članica. Razmjena s ostatkom EMU-12 izražena kao postotak ukupne robne razmjene prvih dvanaest članica smanjila se do 2016. godine - djelomično kao posljedica jačanja njihove razmjene s novim članicama EU-a - ali je i dalje na visokoj razini (tablica 1).

\begin{tabular}{|c|c|c|c|c|}
\hline & 199 & & 2016 & \\
\hline & \% ukupne razmjene & $\%$ BDP-a & $\%$ ukupne razmjene & \% BDP-a \\
\hline Luksemburg & 77,3 & 70,3 & 73,1 & 51,0 \\
\hline Portugal & 68,8 & 34,7 & 64,9 & 39,8 \\
\hline Austrija & 62,5 & 39,5 & 52,5 & 43,2 \\
\hline Belgija & 61,0 & 77,8 & 54,0 & 92,1 \\
\hline Španjolska & 59,4 & 22,4 & 48,7 & 24,1 \\
\hline Nizozemska & 53,3 & 51,5 & 45,3 & 64,7 \\
\hline Grčka & 53,1 & 13,7 & 35,2 & 13,9 \\
\hline Francuska & 52,7 & 22,4 & 51,4 & 22,4 \\
\hline Italija & 51,0 & 18,6 & 40,9 & 19,6 \\
\hline Njemačka & 43,3 & 19,7 & 38,0 & 26,3 \\
\hline Finska & 35,7 & 19,7 & 36,4 & 18,8 \\
\hline Irska & 31,7 & 38,3 & 33,8 & 23,4 \\
\hline
\end{tabular}

Izvori: MMF i izračun autora.

Kriterij financijske integracije države članice su uvelike zadovoljile, ali je ta financijska integracija dovela do visokih makroekonomskih neravnoteža. Naime, osnivanje EMU-a potaknulo je financijsku integraciju među članicama, što se posebice odnosi na novčana tržišta te na tržišta javnog duga, na kojima je ubrzo nakon formiranja europodručja zabilježena potpuna konvergencija prinosa (De Grauwe i Mongelli, 2005). Međutim, 
intenzivni financijski tokovi unutar europodručja nisu imali stabilizirajući učinak, nego su podgrijavali neodrživu cikličku ekspanziju u pojedinim članicama. Slika 1 prikazuje dinamiku salda tekućih računa država jezgre, a to su Njemačka, Francuska, Belgija, Nizozemska, Austrija i Luksemburg, u odnosu na dinamiku salda tekućih računa rubnih država članica Grčke, Irske, Španjolske i Portugala. Primjetljivo je da su u razdoblju od uspostavljanja EMU-a do svjetske financijske krize rubne države ustrajno bilježile manjkove, a države jezgre viškove na tekućim računima platnih bilanci. Pogoršanje salda tekućih računa rubnih država izravno se povezuje s jačanjem prekograničnih kapitalnih tokova nakon osnivanja EMU-a. Uvođenjem zajedničke valute eliminiran je rizik deprecijacije nacionalnih valuta, usidrena su inflacijska očekivanja i znatno su snižene premije za kreditni rizik države, što je dovelo do zamjetnog smanjenja troška inozemnog zaduživanja rubnih članica (Ehrmann, Fratzscher, Gürkaynak i Swanson, 2007; Buiter i Sibert, 2005). Kamatne stope na kredite banaka u rubnim državama također su se osjetno smanjile, što je u uvjetima povišene razine poslovnog i potrošačkog optimizma dovelo do snažnog jačanja potražnje stanovništva i poduzeća za kreditima. Visoku kreditnu potražnju banke su financirale kapitalom iz inozemstva, pri čemu su njihovi vjerovnici najčešće bile banke iz država jezgre poput Njemačke, Francuske i Nizozemske (Hale i Obstfeld, 2014).

U početku je prevladavalo uvjerenje da su neravnoteže u rubnim državama prirodna pojava povezana s procesom realne konvergencije te da ne predstavljaju rizik za europodručje kao cjelinu (Blanchard i Giavazzi, 2002; Campa i Gavilan, 2006; Ahearne, von Hagen i Schmitz, 2007; Ca'Zorzi i Rubaszek, 2008). Međutim, nakon izbijanja svjetske financijske krize postalo je jasno da su visoke neravnoteže u rubnim državama u prethodnom razdoblju zapravo bile odraz ozbiljnog pregrijavanja njihovih gospodarstava, zbog čega su te države bile izrazito snažno pogođene globalnim poremećajima (Gros, 2012; Holinski, Kool i Muysken, 2012; Wyplosz, 2013). 


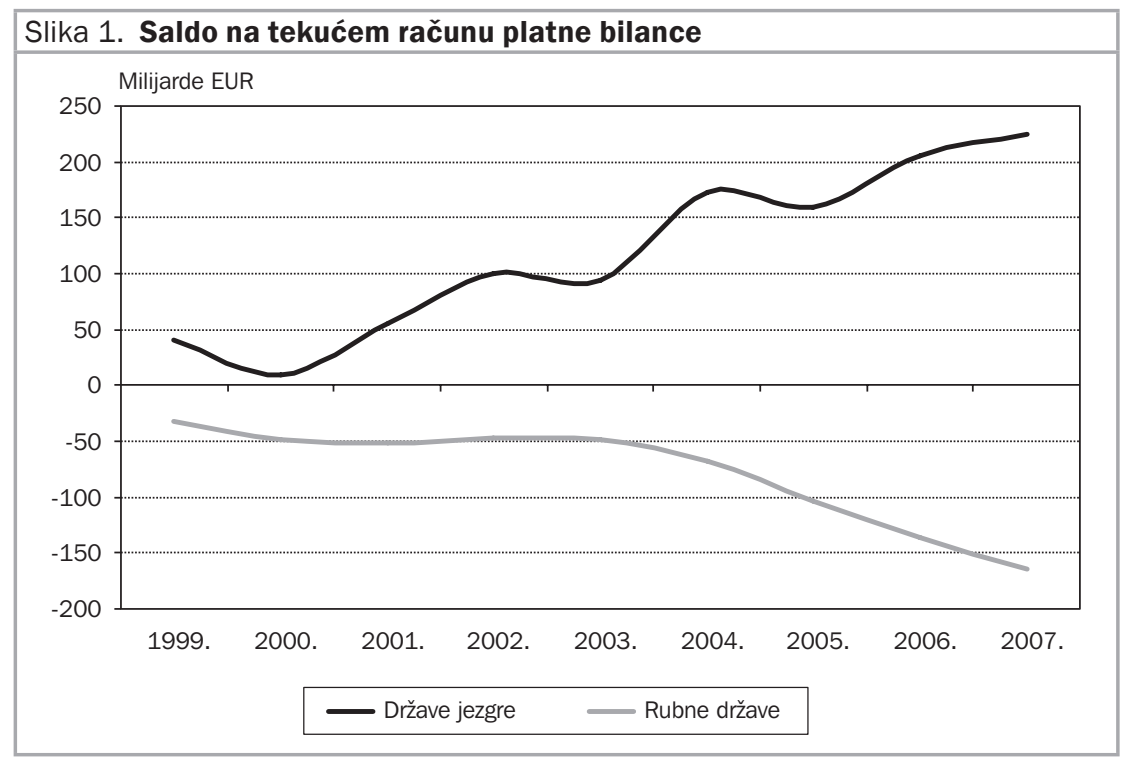

Izvori: Eurostat i izračun autora.

Makroekonomske neravnoteže koje su se nagomilale u rubnim državama pod utjecajem obilnog priljeva kapitala povećale su izloženost tih država negativnom šoku potražnje. Činjenica je da inozemni kapital koji su primile rubne članice nakon osnivanja EMU-a nije bio apsorbiran u produktivnim djelatnostima. Inozemni kapital koji je tada pritjecao u rubne države uglavnom se odnosio na inozemno zaduživanje banaka koje su na taj način kreditirale potrošnju stanovništva i investicije u stanogradnju (Gros, 2012). U takvim uvjetima, rubne članice su doživjele nepovoljne strukturne promjene, pri čemu dolazi do ekspanzije djelatnosti orijentiranih na domaće tržište, poput građevinarstva, poslovanja nekretninama i trgovine (slika 2). Zbog pretjerane ovisnosti o priljevu inozemnoga kapitala i snažnoj domaćoj potražnji, rubne članice bile su mnogo ranjivije na pogoršanje uvjeta financiranja od ostalih članica europodručja. Postupno stezanje uvjeta financiranja i domaće potražnje u rubnim državama započelo je 2007. pod utjecajem pooštravanja monetarne politike Europske središnje banke (Central Bank of Ireland, 2007; Banco de Espana, 2010). Makroekonomski uvjeti dodatno su se snažno pogoršali nakon intenziviranja financijske 
krize u rujnu 2008. godine. Duboka recesija u rubnim državama u velikoj je mjeri bila odraz korekcije viška kapaciteta u djelatnostima koje su prije krize ostvarile neodrživu ekspanziju. U Španjolskoj i Irskoj je, primjerice, građevinarstvo bilo odgovorno za otprilike polovinu ukupnog pada BDV-a i broja zaposlenih tijekom recesije..$^{10}$

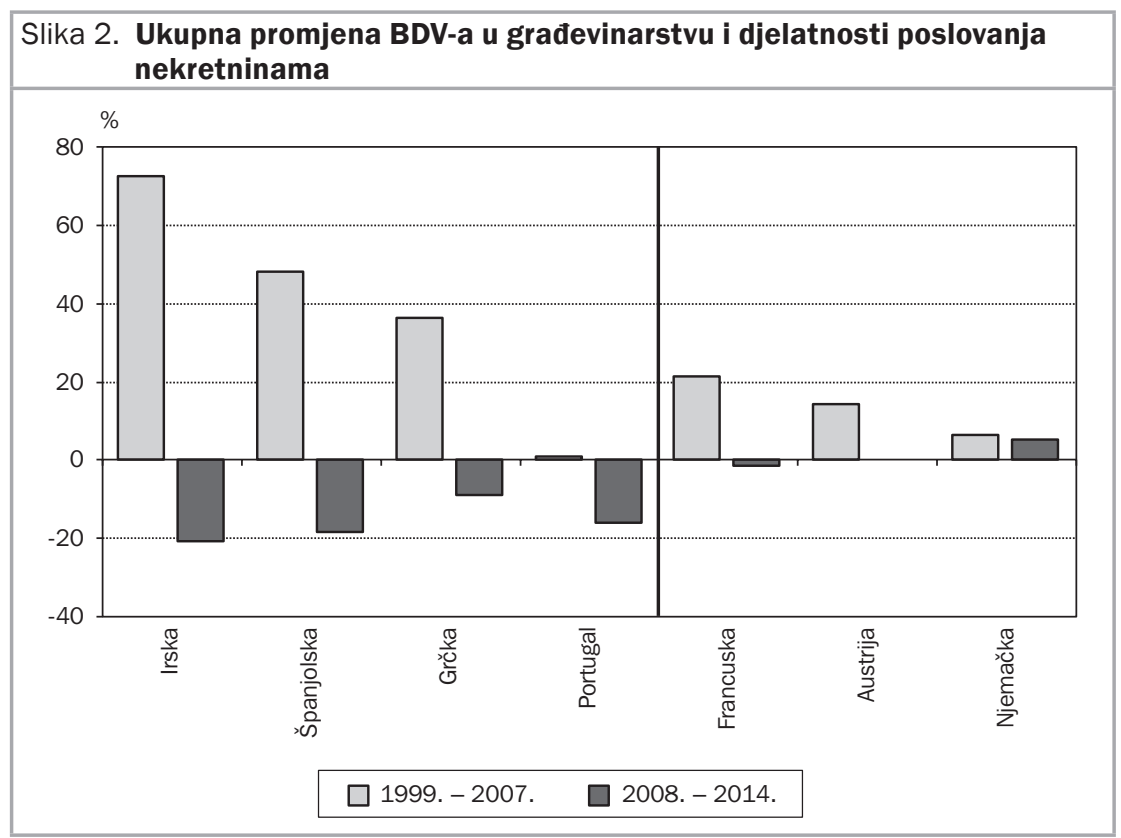

Izvor: Eurostat.

Jedna od vidljivih posljedica krize bilo je smanjenje stupnja financijske integriranosti među članicama, što se povezuje s povećanom averzijom investitora prema riziku. Pritom su investitori posebno diskriminirali rubne države europodručja koje su se nakon izbijanja svjetske financijske krize našle u dužničkim poteškoćama. Primjerice, kao posljedica znatnih fiskalnih rizika, banke iz rubnih država gotovo su potpuno izgubile pristup europskom međubankovnom tržištu, pa im je preostalo jedino zaduživanje kod Europske središnje banke. Globan i Sorić (2017) utvrđuju da je slabljenje integracije bilo još izraženije na tržištu javnog duga, pri čemu su strani

${ }_{10}$ Izračun autora na osnovi podataka Eurostata. 
investitori počeli izbjegavati obveznice država koje su se nalazile u žarištu dužničke krize, poput Grčke i Portugala.

Nekontrolirani rast neravnoteža u rubnim državama može se djelomično povezati i s time što članice europodručja nisu postigle zadovoljavajuću razinu političke integracije u smislu spremnosti na provedbu zajedničkih pravila i prenošenje dodatnih ovlasti na zajednička nadnacionalna tijela. Naime, uvođenjem eura članice su se odrekle vlastitih valuta i samostalnih monetarnih politika, ali su zadržale gotovo potpunu autonomiju kada je riječ o fiskalnoj i strukturnoj politici. Iako su u području fiskalne politike zajednička pravila formalno postojala, članice se tih pravila uglavnom nisu pridržavale. Naime, Pakt o stabilnosti i rastu obvezivao je države članice na postizanje uravnoteženoga ili pozitivnoga proračunskog salda u srednjoročnom razdoblju, a većina njih je unatoč povoljnim makroekonomskim uvjetima bilježila povišene proračunske manjkove. Nadalje, na razini europodručja nije postojao mehanizam nadzora koji bi evidentirao druge makroekonomske ranjivosti - poput platnobilančnih neravnoteža ili prekomjernog kreditnog rasta - i poticao nacionalne vlasti na provođenje mjera s ciljem uklanjanja tih ranjivosti. Međutim, čak i da je takav mehanizam postojao, pitanje je bi li on osigurao pravodobno uklanjanje makroekonomskih neravnoteža, s obzirom na to da tada $\mathrm{u}$ europodručju nije postojala svijest o ekonomskim troškovima koji mogu proizaći iz visokih neravnoteža na razini pojedinih članica. ${ }^{11}$

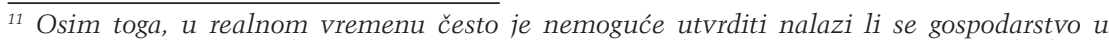
pretjeranoj ekspanziji ili je riječ o održivom gospodarskom rastu. Zbog toga ponekad nije lako odrediti koliko snažne protucikličke mjere trebaju biti da bi se ekspanzija obuzdala. Primjerice, Španjolska i Irska su u razdoblju od 2005. do 2007. ostvarivale proračunske viškove, što je u uvjetima snažnog gospodarskog rasta rezultiralo zamjetnim padom omjera javnog duga i BDP-a. Mnogima se tada činilo da je fiskalna politika u tim državama razborita te da pridonosi njihovoj makroekonomskoj otpornosti. Španjolska je tijekom faze ekspanzije vodila i protucikličku makroprudencijalnu politiku, koristeći mjeru dinamičkog rezerviranja kojom se banke obvezuje da tijekom razdoblja kreditnog rasta izdvajaju rezerve za gubitke koji bi mogli nastati u silaznoj fazi ciklusa (Međunarodni monetarni fond, 2006). Irske su banke u razdoblju prije krize bile relativno visoko kapitalizirane. Međutim, kasnije se ispostavilo da ni javne financije ni bankovni sustavi tih dviju država nisu bili spremni da podnesu duboku i dugotrajnu recesiju. Naime, produbljivanjem recesije došlo je do snažnog pogoršanja fiskalnih pokazatelja, čime je otkriveno da se prethodna fiskalna konsolidacija temeljila na ciklički izrazito povolinim ostvarenjima nominalnog BDP-a i proračunskog salda. Kada je riječ o bankovnim sustavima, znatni kreditni gubici - uvelike povezani s korekcijom tržišta nekretnina - iscrpili su zaštitne slojeve banaka pa su se obje države u konačnici suočile s bankovnom krizom.
} 
Naposljetku, nadzor i sanacija financijskih institucija također su bili isključivo u nadležnosti država članica, što je stvorilo prostor za negativnu povratnu spregu između bilanci banaka i javnih financija. Naime, s obzirom na to da je briga o financijskoj stabilnosti bila odgovornost isključivo nacionalnih nadzornih tijela, sistemski rizici koji su bili istodobno prisutni u većem broju država - poput rizika povezanih s pregrijavanjem tržišta nekretnina i intenzivnim inozemnim zaduživanjem banaka - nisu bili pravodobno prepoznati i ublaženi. Kada su se ti rizici materijalizirali, banke su se suočile s visokim gubicima, a njihova dokapitalizacija financirala se, u pravilu, iz državnih proračuna. U nekim državama - posebice u Irskoj i Španjolskoj - fiskalni trošak sanacije posrnulih banaka bio je toliko visok da je održivost javnog duga došla u pitanje. Međutim, treba napomenuti da u nekoliko država negativna povratna sprega banaka i državnih financija nije bila potaknuta poremećajima u bankovnom sustavu, nego visokim fiskalnim neravnotežama. Naime, u državama poput Grčke, Portugala i Italije likvidnosne poteškoće banaka bile su posljedica snažnog povećanja premije rizika za državu u uvjetima ubrzanog rasta javnog duga i općenito loših makroekonomskih fundamenata. Stoga se može reći da nepostojanje zaštitnih mehanizama koji bi ograničili negativno međudjelovanje između bilanci banaka i države također potvrđuje da EMU-12 nije bio optimalno valutno područje.

Kriterij fiskalne integracije u izvornom europodručju također nije bio zadovoljen. U suprotnosti s drugim velikim valutnim područjima, u europodručju ne postoji sustav fiskalnih transfera namijenjen regijama ili državama koje se suočavaju s negativnim makroekonomskim šokom (Allard i sur., 2013). Iako države članice EU-a raspolažu zajedničkim proračunom, taj proračun je relativno mali i ne sadržava instrumente za kratkoročnu pomoć u slučaju recesije. Osim toga, pravni okvir EU-a izričito zabranjuje Europskoj uniji i članicama preuzimanje dugova drugih članica (tzv. no bailout odredba). Međutim, neugodno iskustvo recentne financijske krize razotkrilo je da ta zabrana nije vjerodostojna, jer u slučajevima snažnoga asimetričnog šoka mora postojati solidarno dijeljenje tereta krize ako se želi očuvati cjelovitost monetarne unije. Tako su nakon izbijanja dužničke krize članice europodručja unatoč formalnoj zabrani 
međusobnog financiranja ipak implicitno preuzele dio tereta fiskalne prilagodbe rubnih država članica. Konkretno, u prvoj polovini 2010. države članice osigurale su Grčkoj putem bilateralnih zajmova znatna sredstva za financiranje programa makroekonomske prilagodbe. Ubrzo nakon toga uspostavljeni su i formalni krizni fondovi, najprije dva privremena fonda, a zatim i trajni - Europski mehanizam za stabilnost (ESM). Sve države članice europodručja dioničari su ESM-a te su stoga bile dužne uplatiti sredstva u njegov kapital, kao i odobriti jamstva koja ESM-u osiguravaju najviši kreditni rejting. Plasmani ESM-a nose niže kamatne stope i znatno su duljih dospijeća u odnosu na zajmove MMF-a, što državama korisnicama pomoći osigurava znatne proračunske uštede (Europski mehanizam za stabilnost, 2016). Ipak, treba naglasiti da ESM nije zamišljen kao sustav fiskalnih transfera koji će stalno biti dostupan članicama. ESM je predviđen za pružanje pomoći samo u slučaju dubokih gospodarskih i financijskih kriza, pri čemu je isplata sredstava uvjetovana dosljednim provođenjem programa makroekonomske prilagodbe odnosno programa restrukturiranja financijskog sektora. Tek kada bi se uspostavila funkcija makroekonomske stabilizacije za europodručje (u obliku zajedničkog sustava za osiguranje nezaposlenih, zajedničkog programa za zaštitu ulaganja ili fonda za nepredviđene situacije), o čemu se trenutno raspravlja u EU-u, ili neki alternativni instrument preraspodjele, moglo bi se govoriti o povećanju fiskalne integracije između država članica (Beblavý, Marconi i Maselli, 2015)..$^{12}$

Prema kriteriju mobilnosti rada europodručje zaostaje za SAD-om. Općenito je niska mobilnost rada značajka europskih gospodarstava. Primjerice, u 2006. godini stopa mobilnosti radnika - izračunata kao omjer broja radnika koji su tijekom posljednje dvije godine promijenili državu i ukupne populacije države - u SAD-u je iznosila 1,9 posto u usporedbi s 0,1 posto u EU-u (Bonin i sur., 2008). Iako te brojke treba uzimati s oprezom zbog različitih definicija regionalnih jedinica u različitim državama, one u slučaju europskih zemalja govore o snažnoj prisutnosti prepreka kretanju

\footnotetext{
${ }_{12}$ Osim postizanja većeg stupnja fiskalne integracije, poduzetim (npr. uspostava stalnog kriznog mehanizma - ESM-a) i najavljenim mjerama (npr. prijedlog o preoblikovanju ESM-a u Europski monetarni fond) pridonosi se uklanjanju institucionalnih slabosti EMU-a i izgradnji cjelovite ekonomske i monetarne unije.
} 
radnika, s jedne strane, te manjku motivacije za mobilnost, s druge. Među glavne prepreke kretanju radnika među državama članicama EU-a spadaju jezične i kulturološke razlike te pravna ograničenja, a u vrijeme uspostavljanja EMU-a to su bile i granične kontrole i različite nacionalne valute (prije implementacije Šengenskog sporazuma i uvođenja eura). Postojanje tih ograničenja objašnjava samo dio razlike između Europe i SAD-a, dok se drugi dio objašnjenja nalazi u činjenici da je američko društvo tradicionalno mobilno, za razliku od europskih naroda, koji se tradicionalno vežu za neke lokacije, što onda utječe na ponašanje stanovništva.

S vremenom se situacija u EU-u mijenja. Europska komisija (2014) navodi da je u 2013. godini ukupno 7 milijuna stanovnika živjelo i radilo izvan svoje zemlje; taj broj čini oko 3,3 posto ukupne zaposlenosti u EU-u. Tijekom krize došlo je do zamjetnog povećanja odljeva stanovništva iz krizom pogođenih zemalja u druge članice, kao i u zemlje izvan EU-a. U ukupnom broju radnika mobilnih unutar EU-a najviše je onih iz država srednje i istočne Europe. Kad je riječ o spremnosti na mobilnost, rezultati istraživanja iz 2013. govore da bi prosječno 25 posto radnika razmotrilo mogućnost rada u drugoj državi članici u sljedećih deset godina.

\subsubsection{Reforma institucionalnog okvira EMU-a nakon 2008.}

Neke od institucionalnih manjkavosti monetarne unije ispravljene su nakon svjetske financijske krize. Najveći napredak ostvaren je kada je riječ o daljnjoj ekonomskoj i političkoj integraciji na razini cijelog EU-a, pri čemu su države članice postigle suglasje o prenošenju dijela nacionalnih nadležnosti - ponajprije u području nadzora financijskog sustava - na zajedničku razinu. Jedna skupina reformi odnosila se na osnaživanje okvira za koordinaciju ekonomskih politika, a u svrhu, s jedne strane, otklanjanja institucionalnih slabosti nacionalnih gospodarstava ${ }^{13} \mathrm{i}$, s druge strane, smanjenja rizika koji

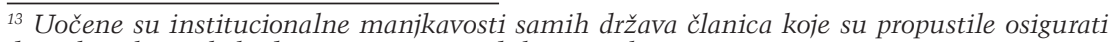
da priljevi kapitala budu usmjereni u produktivne sektore, a na što se može utjecati is razine EU-a. Gros (2011) na primjeru Italije obrađuje fenomen "izgubljenog desetljeća" u toj zemlji unatoč činjenici da su se faktori rasta poboljšali, objašnjavajući ga niskom kvalitetom institucija odnosno ukupnog upravljanja u zemlji te potrebom poduzimanja napora usmjerenih na borbu protiv korupcije, jačanje vladavine prava i unaprjeđenje javne uprave. 
proizlaze iz loših politika na nacionalnoj razini. Pakt o stabilnosti i rastu osnažen je i u preventivnom i u korektivnom dijelu. U preventivnom dijelu uveden je koncept srednjoročnog fiskalnog cilja, pri čemu se države članice obvezuju održavati svoja strukturna proračunska salda blizu ravnoteže, a propisana su i ograničenja vezana uz rast javne potrošnje. U korektivnom dijelu Pakta glavna promjena je izjednačavanje važnosti kriterija javnog duga i kriterija proračunskog manjka. Kao rezultat te promjene, postupak u slučaju prekomjernog manjka sada se može pokrenuti i ako proračunski manjak ne prelazi dozvoljene okvire, uz uvjet da je prekoračena referentna vrijednost za javni dug. Među institucionalnim reformama EMU-a svakako treba istaknuti i pokretanje Europskog semestra. U okviru godišnjeg ciklusa Europskog semestra institucije EU-a ocjenjuju kvalitetu fiskalnih i strukturnih politika u državama članicama te upućuju preporuke nacionalnim vlastima. Važan novi element u koordinaciji ekonomskih politika EU-a je postupak u slučaju makroekonomskih neravnoteža, kojim se nastoji povećati svijest država članica o važnosti izbjegavanja i pravodobnog ispravljanja makroekonomskih neravnoteža. $\mathrm{Na}$ taj se način želi smanjiti vjerojatnost da članice u budućnosti dožive prekomjernu akumulaciju neravnoteža kao što je bio slučaj u rubnim državama tijekom 2000-ih (Brkić i Šabić, 2014).

Druga skupina reformi usredotočena je na jačanje otpornosti financijskih institucija i povećanje sposobnosti regulatora da pravodobno ublaže rizike. Ključna reforma u ovom području bila je osnivanje bankovne unije koja, među ostalim, podrazumijeva prenošenje ovlasti za prudencijalni nadzor banaka u europodručju na zajedničkog supervizora, Europsku središnju banku. Ovim putem uklonjena je manjkavost institucionalnog okvira EMU-a prema kojemu je nadzor nad bankama ostao isključiva odgovornost nacionalnih tijela, unatoč postojanju zajedničke monetarne politike. Osim toga, uspostavljanjem bankovne unije harmonizirani su nacionalni regulatorni okviri za sanaciju banaka, pri čemu je uspostavljen zajednički sustav sanacije banaka (Single Resolution Board, SRB) koji će od 2024. godine podupirati potpuno kapitalizirani sanacijski fond (Single Resolution Fund, SRF). Države članice još nisu postigle dogovor oko trećeg stupa bankovne unije - zajedničkog sustava osiguranja depozita. Nadalje, 
u razdoblju nakon krize znatno je porasla svijest o značenju sistemskih rizika, a time i o važnosti makroprudencijalnih instrumenata kao alata za njihovo ublažavanje. Kako bi se formalizirao nadzor nad sistemskim rizicima, na razini EU-a osnovan je Europski odbor za sistemske rizike (ESRB) s mandatom da motri sistemske rizike i ranjivosti te koordinira nacionalna makroprudencijalna tijela (Europski odbor za sistemske rizike, 2014a). Pritom treba naglasiti da je nakon svjetske financijske krize bankovna regulativa u EU-u upotpunjena nizom novih instrumenata kojima se može izravno utjecati na uzročnike sistemskih rizika. Regulatori tako sada mogu nametati i otpuštati zaštitne slojeve kapitala kako bi povećali otpornost banaka na šokove i ublažili procikličnost kreditne aktivnosti, povećavati pondere rizika kako bi usporili rast izloženosti prema specifičnim sektorima, a uvedeni su i znatno stroži likvidnosni standardi koji bi trebali smanjiti ročnu neusklađenost u bilancama banaka (Europski odbor za sistemske rizike, 2014b).

Uz pretpostavku da će novi mehanizmi koordinacije povećati disciplinu nositelja ekonomskih politika te da će makroprudencijalna politika biti djelotvorna u ublažavanju financijskih rizika, vjerojatnost novih dubokih ekonomskih i financijskih kriza u europodručju trebala bi biti manja nego u prošlosti. U takvim uvjetima rizik pojave divergentnih makroekonomskih kretanja trebao bi se smanjiti, što bi moglo pridonijeti otpornosti i dugoročnoj održivosti monetarne unije.

\section{Ocjena primjerenosti eura za Hrvatsku prema teoriji optimalnih valutnih područja}

U nekoliko ranijih studija ispituje se je li Hrvatska dovolino kompatibilna s razvijenim članicama EU-a odnosno europodručja da bi mogla uspiešno funkcionirati u monetarnoj uniji, od kojih posebno vrijedi istaknuti radove Šonje i Vrbanc (2000), Belullo i sur. (2000), Broz (2008) te Kotarac i sur. (2017). U tim radovima naglasak je na vrednovanju usklađenosti poslovnih ciklusa između Hrvatske i odabranih država jezgre europodručja. Premda se kriterij usklađenosti poslovnih ciklusa s pravom ističe kao najvažniji 
kriterij - jer je visok stupanj usklađenosti ciklusa nužan da bi zajednička monetarna politika podjednako odgovarala svim članicama - ostali kriteriji također mogu pružiti važna saznanja o tome isplati li se nekoj državi pristupiti monetarnoj uniji ili ne. Stoga se u nastavku analiziraju ostvarenja Hrvatske prema svim ključnim kriterijima teorije optimalnih valutnih područja. Pritom se također podsjeća na specifična obilježja hrvatskoga gospodarstva zbog kojih ta teorija ne može biti jedino mjerilo za odlučivanje o primjerenosti eura za Hrvatsku.

\subsection{Trgovinska i financijska integracija}

Hrvatska je trgovinski visoko integrirana s državama članicama europodručja, pa stoga stabilnost deviznog tečaja kune prema euru pogoduje hrvatskom gospodarstvu. Naime, malim otvorenim gospodarstvima pretjerana kolebljivost deviznog tečaja ne odgovara jer česte promjene uvjeta razmjene mogu ugroziti stabilnost cijena. Primjerice, kad bi kuna znatnije oslabila prema euru, uvozni proizvodi koji imaju visok udio u košarici za izračun indeksa potrošačkih cijena poskupjeli bi, što bi generiralo porast ukupne stope inflacije u Hrvatskoj. Osim toga, deprecijacija tečaja dovela bi do poskupljenja uvoznih sirovina i intermedijarnih proizvoda, a time i do povećanja proizvodnih troškova za domaća poduzeća.

U uvjetima visoke uvozne ovisnosti hrvatskoga gospodarstva - zbog čega promjene cijena uvoznih dobara značajno utječu na ukupnu stopu inflacije ${ }^{14}$ - stabilnost nominalnog tečaja kune prema euru važno je sidro za inflacijska očekivanja domaćih gospodarskih subjekata.

\footnotetext{
${ }^{14}$ Dosad je provedeno nekoliko istraživanja na temu odrednica stope inflacije u Hrvatskoj. U tim se radovima utvrđuje da su cijene uvoznih proizvoda važan činitelj agregatne stope inflacije, što ne iznenađuje s obzirom na visok stupanj otvorenosti hrvatskoga gospodarstva (Krznar i Kunovac, 2010; Krznar, 2011; Jovičić i Kunovac, 2017). Iz tog razloga pokazatelji gospodarske aktivnosti i troška rada u domaćem gospodarstvu ne mogu u dovolinoj mjeri objasniti dinamiku stope inflacije, pa je pri modeliranju inflacije potrebno ukliučiti i varijablu koja odražava cijene intermedijarnih i kapitalnih proizvoda koji se uvoze iz inozemstva.
} 


\section{Slika 3. Razmjena s europodručjem u ukupnoj robnoj razmjeni u trenutku}

ulaska u ERM II

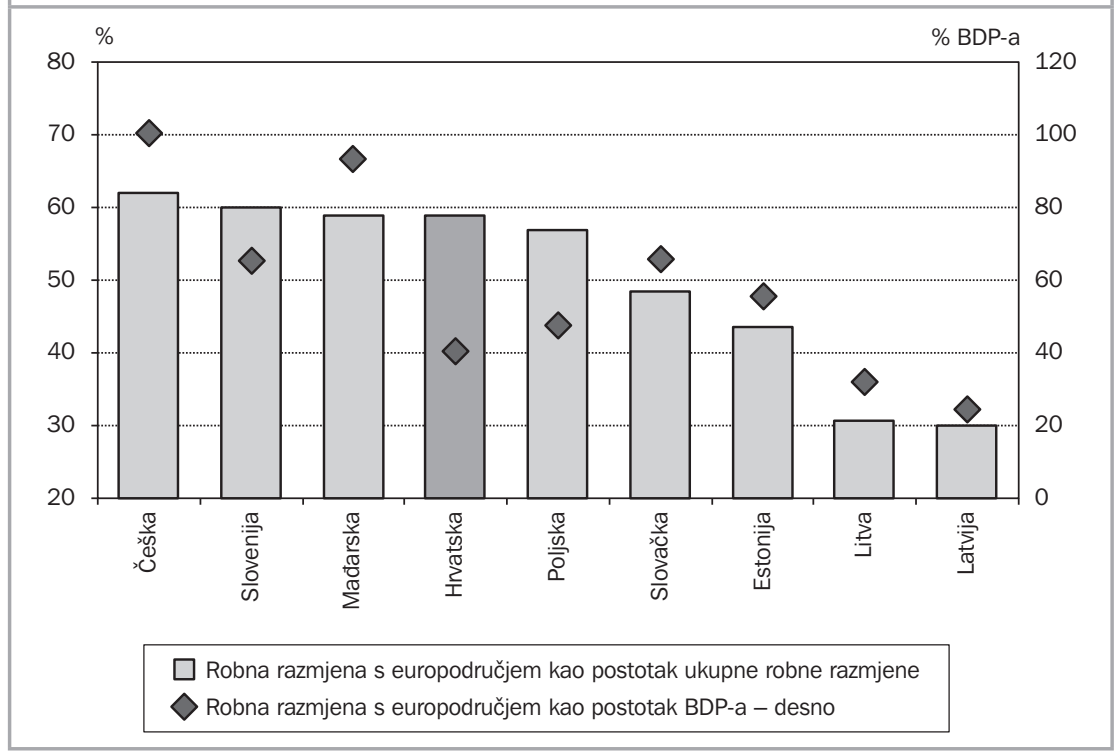

Napomena: Podaci se odnose na 2016. ako država još nije pristupila tečajnom mehanizmu. Države koje još nisu pristupile tečajnom mehanizmu su Čěka, Mađarska, Hrvatska i Poljska. Izvori: IMF Direction of Trade Statistics i Eurostat.

Robna razmjena s državama članicama europodručja tradicionalno čini više od polovine ukupne robne razmjene Hrvatske (slika 3). Nakon ulaska Hrvatske u EU 2013. godine vanjskotrgovinska razmjena s državama članicama europodručja dodatno je ojačala te sada njezin udio doseže gotovo 60 posto (slika 4). Ako se promatra samo ovaj pokazatelj, Hrvatska se čini jednako snažno povezana s europodručjem kao i ostale države srednje i istočne Europe te relativno snažnije povezana nego što su baltičke države bile u trenutku pristupanja tečajnom mehanizmu sredinom prošlog desetljeća. Međutim, kako je razina otvorenosti hrvatskoga gospodarstva relativno niska u usporedbi s ostalim novim članicama, obujam robne razmjene s europodručjem iskazan u postocima BDP-a i nadalje je znatno niži nego primjerice u Češkoj i Mađarskoj (slika 3). Ipak, čak i kada se intenzitet vanjskotrgovinskih odnosa s europodručjem mjeri u terminima 
BDP-a, Hrvatska je mnogo snažnije integrirana od Finske, Grčke i Irske, koje su europodručju pristupile prije više od petnaest godina ${ }^{15}$.

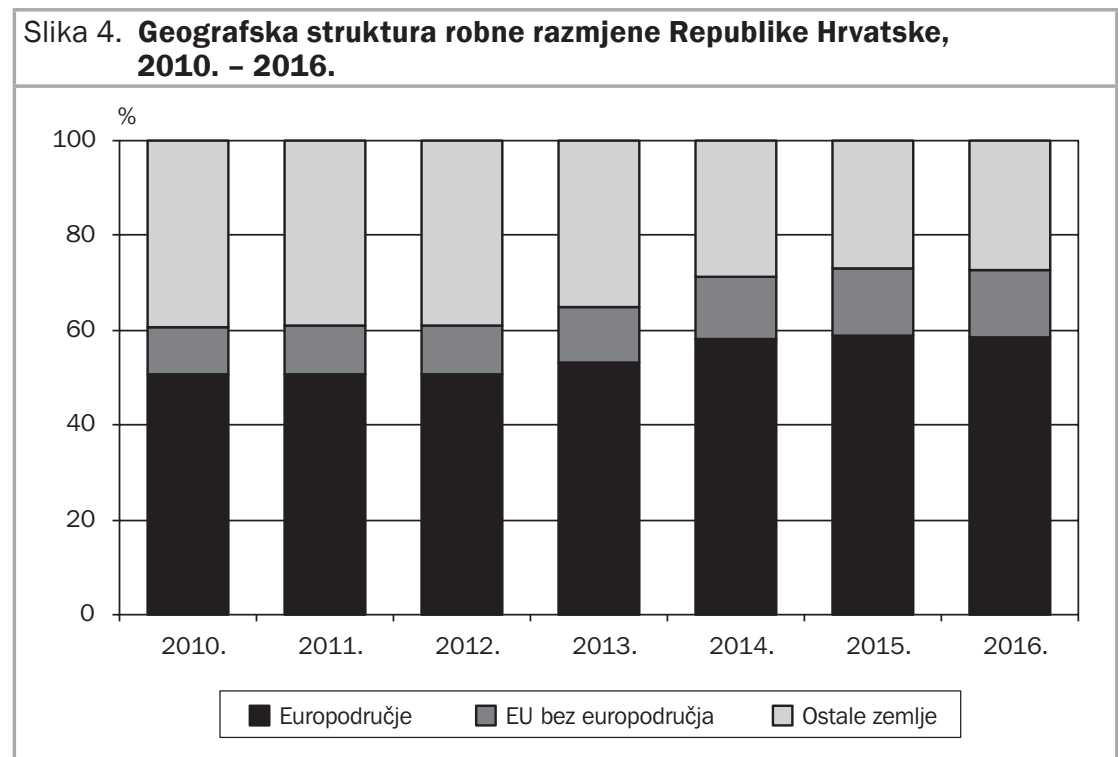

Izvori: IMF Direction of Trade Statistics i izračun autora.

S obzirom na to da ključni vanjskotrgovinski partneri koriste euro kao nacionalnu valutu, vjerojatnost da se Hrvatska u razdoblju nakon uvođenja eura suoči s padom konkurentnosti zbog deprecijacije valute važnoga vanjskotrgovinskog partnera vrlo je niska. U tom kontekstu treba napomenuti i to da važni vanjskotrgovinski partneri Hrvatske izvan EU-a, Bosna i Hercegovina i Srbija, devizne tečajeve svojih valuta održavaju stabilnima u odnosu na euro ${ }^{16}$. Iz toga proizlazi da Hrvatska približno 70 posto svoje robne razmjene ostvaruje s državama koje ili koriste euro ili tečajeve svojih valuta vežu uz euro. Nadalje, članice europodručja i navedene susjedne države ujedno su i ključna emitivna tržišta za turizam

\footnotetext{
${ }^{15}$ Prema podacima MMF-a, Irska, Finska i Grčka ostvarile su u 2015. robnu razmjenu s europodručjem u vrijednosti od 23, 19 odnosno 14 posto BDP-a.

${ }_{16}$ Središnja banka BiH od svog utemeljenja 1997. primjenjuje režim valutnog odbora, pri čemu je valuta u početku bila vezana uz njemačku marku, a kasnije uz euro. Središnja banka Srbije primjenjuje režim ciljanja inflacije, ali uz česte devizne intervencije kojima nastoji ograničiti fluktuacije deviznog tečaja dinara u odnosu na euro.
} 
kao stratešku uslužnu djelatnost ${ }^{17}$, pri čemu su mediteranske države europodručja istodobno i glavni konkurenti Hrvatske u toj djelatnosti.

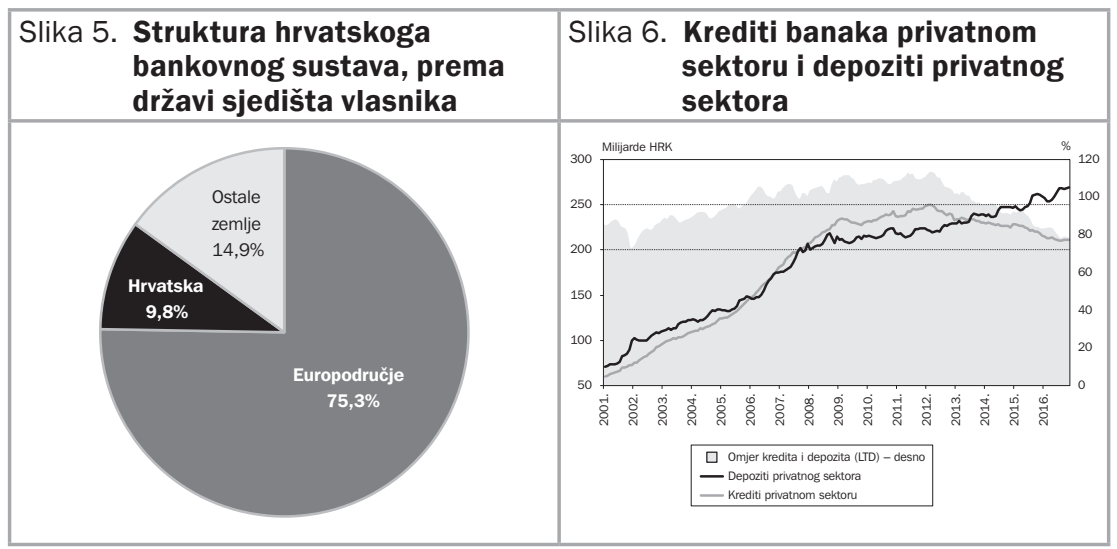

Izvori: HNB i izračun autora.

Izvori: HNB i izračun autora.

Osim trgovinske integracije, Hrvatsku karakterizira i visok stupanj financijske integracije s članicama europodručja. Znatna participacija banaka iz europodručja u hrvatskom bankovnom sustavu glavni je oblik te integracije. Prema podacima za kraj 2016., banke u vlasništvu financijskih institucija iz europodručja posjedovale su približno tri četvrtine ukupne aktive hrvatskoga bankovnog sustava (slika 5). Financijski tokovi između inozemnih banaka majki i njihovih banaka kćeri u Hrvatskoj pokazali su se kao značajan kanal prelijevanja monetarnih impulsa iz europodručja na hrvatsko gospodarstvo. Kako navodi Rohatinski (2015), u prvoj polovini prošlog desetljeća inozemne banke matice zaduživale su se u europodručju po niskim kamatnim stopama, a potom su ta sredstva plasirale bankama kćerima u Hrvatskoj, gdje je prinos na imovinu bio znatno viši ${ }^{18}$ Podaci prikazani na slici 6 potvrđuju da su se domaće banke u godinama uoči

\footnotetext{
${ }_{17}$ Naime, prema fizičkim pokazateljima za 2015. godinu gosti iz članica europodručja, Srbije te Bosne i Hercegovine ostvarili su oko dvije trećine ukupnih dolazaka i noćenja u Hrvatskoj u toj godini.

${ }^{18}$ Globan (2014) empirijski dokazuje vezu između kapitalnih priljeva u nove države članice EU-a i šokova vezanih uz domaću i inozemnu kamatnu stopu. Međutim, iako su kamatni šokovi imali važnu ulogu u definiranju kapitalnih tokova sredinom prošlog desetljeća, ovaj autor pronalazi da se njihov utjecaj nakon izbijanja krize u jesen 2008. zamjetno smanjio, vjerojatno kao rezultat povećanja averzije prema riziku na međunarodnim tržištima.
} 
svjetske financijske krize služile inozemnim kapitalom kako bi financirale kreditnu ekspanziju. Sredinom prošlog desetljeća krediti privatnom sektoru rasli su brže od domaće depozitne baze, odnosno omjer kredita i depozita je porastao, što upućuje na zaključak da su banke uvozile inozemni kapital kako bi ostvarile željene stope rasta kredita. Nakon što je kriza započela, banke u inozemnom vlasništvu odlučile su znatno usporiti kreditnu aktivnost te smanjiti korištenje inozemnih izvora financiranja, što je dovelo do postupnog pada omjera kredita i depozita na razini bankovnog sustava (slika 6). Može se stoga zaključiti da snažna financijska integracija s europodručjem nije imala blagotvoran učinak na hrvatsko gospodarstvo u smislu mogućnosti izglađivanja potrošnje i dohotka tijekom poslovnog ciklusa. Upravo suprotno, u fazi gospodarskog uzleta tokovi kapitala između banaka matica u europodručju i njihovih hrvatskih subsidijara dodatno su podgrijavali ekspanziju domaće potražnje u Hrvatskoj, dok je u fazi recesije nastupilo intenzivno razduživanje subsidijara prema maticama, što je imalo negativne implikacije na raspoloživost kredita u hrvatskom gospodarstvu. I u ostalim posttranzicijskim europskim državama kapital je u razdoblju prije krize pritjecao uglavnom pod utjecajem vanjskih financijskih činitelja (npr. visina kamatnih stopa u europodručju), a ne realnih činitelja (npr. produktivnost domaćeg gospodarstva). Problem je u tome što kapitalni tokovi vođeni vanjskim financijskim činiteljima mogu biti izrazito volatilni, što znatno otežava vođenje ekonomske politike. Globan (2015) empirijski dokazuje da je zastoj u kapitalnim priljevima nakon 2008. bio osobito izražen u onim državama koje su prije krize primile velike količine kapitala po osnovi vanjskih financijskih činitelja.

Financijska povezanost Hrvatske i europodručja ogleda se i u visokom udjelu europodručja u ukupnim priljevima inozemnih izravnih ulaganja u Hrvatsku. Naime, rezidenti europodručja emitenti su gotovo tri četvrtine ukupnih inozemnih izravnih ulaganja zabilježenih u Hrvatskoj u razdoblju od 1993. do 2016. godine. Treba napomenuti da se pojedinačno najveći dio tih ulaganja odnosi na stjecanje vlasništva nad domaćim bankama i njihovu dokapitalizaciju, ali zabilježena su ulaganja i u druge, većinom uslužne djelatnosti, kao što su trgovina na veliko i malo, poslovanje nekretninama te pošta i telekomunikacije. Izravna ulaganja u prerađivačku 
industriju čine manje od 20 posto ukupnih ulaganja. Financijski odnosi između Hrvatske i europodručja znatno su slabiji u području transakcija s vrijednosnicama. Hrvatsko tržište kapitala vrlo je plitko i slabo likvidno te je stoga neatraktivno za inozemne ulagače. ${ }^{19}$ Istodobno, ulaganja u dionice i udjele u investicijskim fondovima ne čine važan oblik financijskog ulaganja hrvatskih kućanstava, a to povratno onemogućuje dinamičniji razvoj domaćeg tržišta kapitala. Slaba razvijenost domaćeg tržišta zrcali se u niskim razinama inozemne imovine i inozemnih obveza Hrvatske na osnovi portfeljnih ulaganja. Naime, prema podacima za kraj 2016. godine, suma imovine i obveza domaćih sektora na osnovi portfeljnih ulaganja u dionice i udjele u investicijskim fondovima iznosila je samo 5 posto BDP-a. Za usporedbu, u razvijenim državama jezgre europodručja suma inozemne imovine i inozemnih obveza na istoj osnovi znatno je viša te iznosi od 44 posto BDP-a u Austriji do čak 209 posto BDP-a u Nizozemskoj. ${ }^{20}$

Kada se uzme u obzir visok intenzitet vanjskotrgovinskih i financijskih odnosa Hrvatske i članica europodručja, može se zaključiti da bi pristupanje monetarnoj uniji moglo imati pozitivne učinke na hrvatsko gospodarstvo. Iako je devizni tečaj kune prema euru i dosad bio relativno stabilan, uvođenjem eura valutni rizik potpuno bi nestao, kao i svi troškovi vezani uz konverziju valuta i zaštitu od valutnog rizika. To bi moglo povećati troškovnu učinkovitost i međunarodnu konkurentnost hrvatskih izvoznika. Pristupanje monetarnoj uniji moglo bi se pozitivno odraziti i na prihode od turizma jer bi Hrvatska time postala još atraktivnija destinacija za rezidente europodručja, i to ponajprije zbog povećanja transparentnosti cijena i ukidanja troškova mjenjačkih poslova. Istodobno, nakon uvođenja eura konkurentnost Hrvatske ne bi bila ugrožena kretanjem tečajeva valuta važnih vanjskotrgovinskih partnera. Naime, kako je već istaknuto, glavnina međunarodne razmjene odnosi se na razmjenu s europodručjem i državama koje tečajeve svojih valuta održavaju stabilnima u odnosu na euro, pa je stoga rizik inozemnoga valutnog šoka za Hrvatsku vrlo nizak.

${ }_{19}$ Derado (2009) navodi da je niska razvijenost tržišta kapitala obilježje većine europskih posttranzicijskih država. Kao jednu od glavnih prepreka za njihovu veću međunarodnu financijsku integriranost ovaj autor ističe prisutnost valutnog rizika, s obzirom na to da većina tih država još uvijek ne koristi euro.

${ }^{20}$ Izračun autora na temelju podataka Eurostata. 


\subsection{Usklađenost poslovnih ciklusa i ekonomskih šokova}

Prema kriteriju usklađenosti poslovnih ciklusa i ekonomskih šokova Hrvatska se doima kao dobar kandidat za uvođenje eura. Kotarac i sur. (2017) na temelju podataka za razdoblje od 1998. do 2016. utvrđuju da se usklađenost između poslovnog ciklusa u Hrvatskoj i poslovnih ciklusa najvećih članica europodručja s vremenom povećavala te se trenutno nalazi na visokoj razini. Za razliku od većine empirijskih radova na temu usklađenosti ciklusa u kojima su uglavnom korištene jednostavne korelacije, u navedenom se istraživanju usklađenost poslovnih ciklusa promatra kao kompozitni pokazatelj koji sadrži dva elementa - mjeru usklađenosti predznaka ciklusa i mjeru usklađenosti amplituda ciklusa. Osim što su utvrdili relativno visoku usklađenost ciklusa, ovi autori pronalaze da su Hrvatska i europodručje izloženi sličnim šokovima agregatne ponude i potražnje, pri čemu su reakcije gospodarstava na te šokove približno simetrične. Na temelju toga autori zaključuju da Hrvatska nakon uvođenja eura ne bi trebala biti izložena asimetričnim šokovima koji bi otežavali vođenje ekonomske politike.

U ranijim radovima, Šonje i Vrbanc (2000) te Belullo i sur. (2000) na temelju podataka o stopama nezaposlenosti za razdoblje od 1992. do 1999. ocjenjuju usklađenost poslovnih ciklusa Hrvatske i nekoliko država srednje Europe u odnosu na poslovni ciklus Njemačke. Pritom zaključuju da realna gospodarska kretanja u Hrvatskoj i drugim državama regije u velikoj mjeri prate kretanja njemačkog poslovnog ciklusa, pri čemu su šokovi koji nastaju u njemačkom gospodarstvu važan činitelj cikličkih fluktuacija u promatranim državama. Visoku usklađenost poslovnog ciklusa Hrvatske s ciklusima razvijenih država članica potvrdili su i Arčabić (2011) i Jovančević, Arčabić i Globan (2012). ${ }^{21}$ S druge strane, Broz (2008) na temelju podataka za razdoblje od 1995. do 2006. ne pronalazi visok stupanj usklađenosti poslovnih ciklusa Hrvatske i razvijenih članica europodručja. Međutim,

${ }^{21}$ Arčabić (2011) računa jednostavnu korelaciju poslovnih ciklusa između Hrvatske i osam članica EU-a (Austrija, Francuska, Niemačka, Nizozemska, Italija, Mađarska, Slovenija i Ujedinjeno Kraljevstvo). S druge strane, Jovančević i sur. (2012) svoju analizu temelje na jednostavnom VAR modelu koji mjeri jesu li gospodarska kretanja u Hrvatskoj pod utjecajem šokova koji potječu iz pet država članica (Austrija, Francuska, Niemačka, Italija i Ujedinjeno Kraljevstvo). 
iako je procijenjena korelacija ciklusa relativno niska ako se promatra cijelo razdoblje, ova autorica pronalazi da se ta korelacija postupno povećavala u skladu s intenziviranjem ekonomske integracije između Hrvatske i članica europodručja.

\subsection{Diversificiranost gospodarstva}

Kriterij diversificiranosti gospodarstva za Hrvatsku je najproblematičniji od svih spomenutih kriterija. Nedovolina diversificiranost hrvatskoga gospodarstva najbolje se prepoznaje u prekomjernoj ovisnosti o sektoru turizma. Prema relativnoj veličini prihoda od turizma (mjereno u terminima BDP-a) Hrvatska odskače čak i u odnosu na druge mediteranske turističke države poput Grčke, Portugala i Španjolske (slika 7). Znatno oslanjanje na turizam izvor je ranjivosti gospodarstva jer je riječ o sektoru koji može biti podložan snažnim kolebanjima, osobito ako se geopolitički rizici (npr. terorizam) povećaju.

Na slici 8 vidljivo je da Hrvatska ustrajno ostvaruje manjak u robnoj razmjeni, što je odraz strukture hrvatskog gospodarstva. Taj strukturni manjak u robnoj razmjeni više je nego pokriven viškom u razmjeni usluga što se gotovo u cijelosti odnosi na prihode sektora turizma u drugom i trećem tromjesečju - tako da na godišnjoj razini Hrvatska u posljednje vrijeme bilježi pozitivan saldo tekućeg računa platne bilance. Takva struktura tekućeg računa važan je izvor ranjivosti gospodarstva. Naime, kad bi snažan negativan šok zamjetno smanjio prihode od turizma, izvjesno je da bi došlo do pogoršanja salda na tekućem računu, što bi izazvalo poremećaje na deviznom tržištu, uz moguće deprecijacijske pritiske na domaću valutu. 


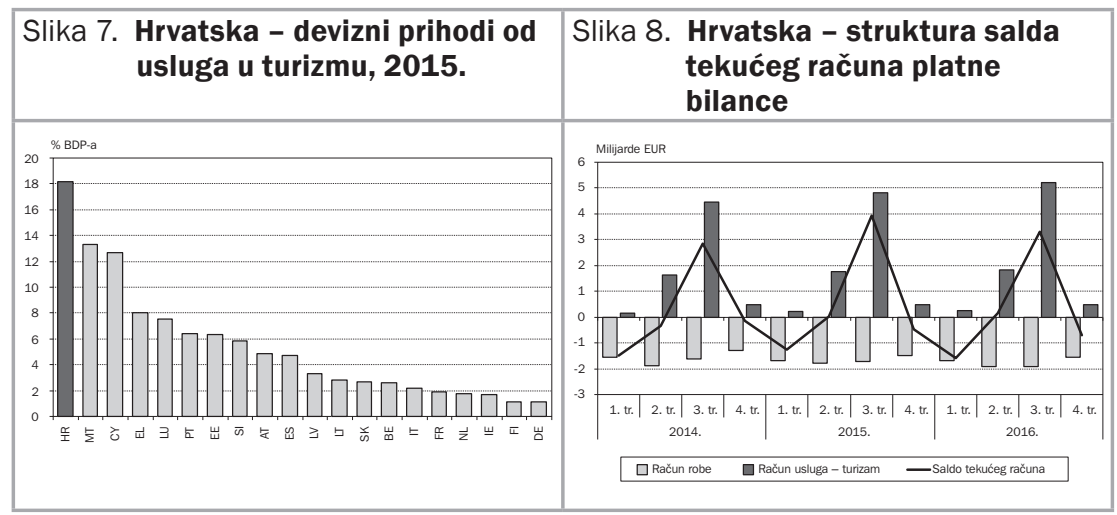

Izvor: Eurostat.

Izvor: $H N B$.

Druga strukturna slabost hrvatskoga gospodarstva povezana je s nepovoljnom strukturom prerađivačke industrije, u kojoj se visok postotak ukupne dodane vrijednosti odnosi na proizvodnju tehnološki manje intenzivnih proizvoda (tablica 2). U Hrvatskoj tako dominantnu ulogu ima proizvodnja hrane i pića, nemetalnih mineralnih proizvoda, proizvoda od drva te odjeće. U tom smislu Hrvatska se uvelike razlikuje od država jezgre europodručja, u kojima su mnogo jače zastupljeni proizvodi s visokom tehnološkom komponentom, poput motornih vozila te strojeva i uređaja. U državama poput Češke i Mađarske struktura industrije znatno je bolje usklađena s onom u europodručju, što odražava visoku integriranost tih država u proizvodne lance poduzeća iz razvijenih država europodručja, posebice Njemačke (Stehrer i Stöllinger, 2015). Hrvatska nije u tolikoj mjeri uključena u lance vrijednosti europskih poduzeća, što se ogleda u relativno niskom intenzitetu unutarsektorske razmjene s europodručjem. Međutim, stupanj unutarsektorske razmjene počeo se snažno povećavati nakon pristupanja Hrvatske EU-u, i to posebice u razmjeni proizvoda više dodane vrijednosti. ${ }^{22}$ 


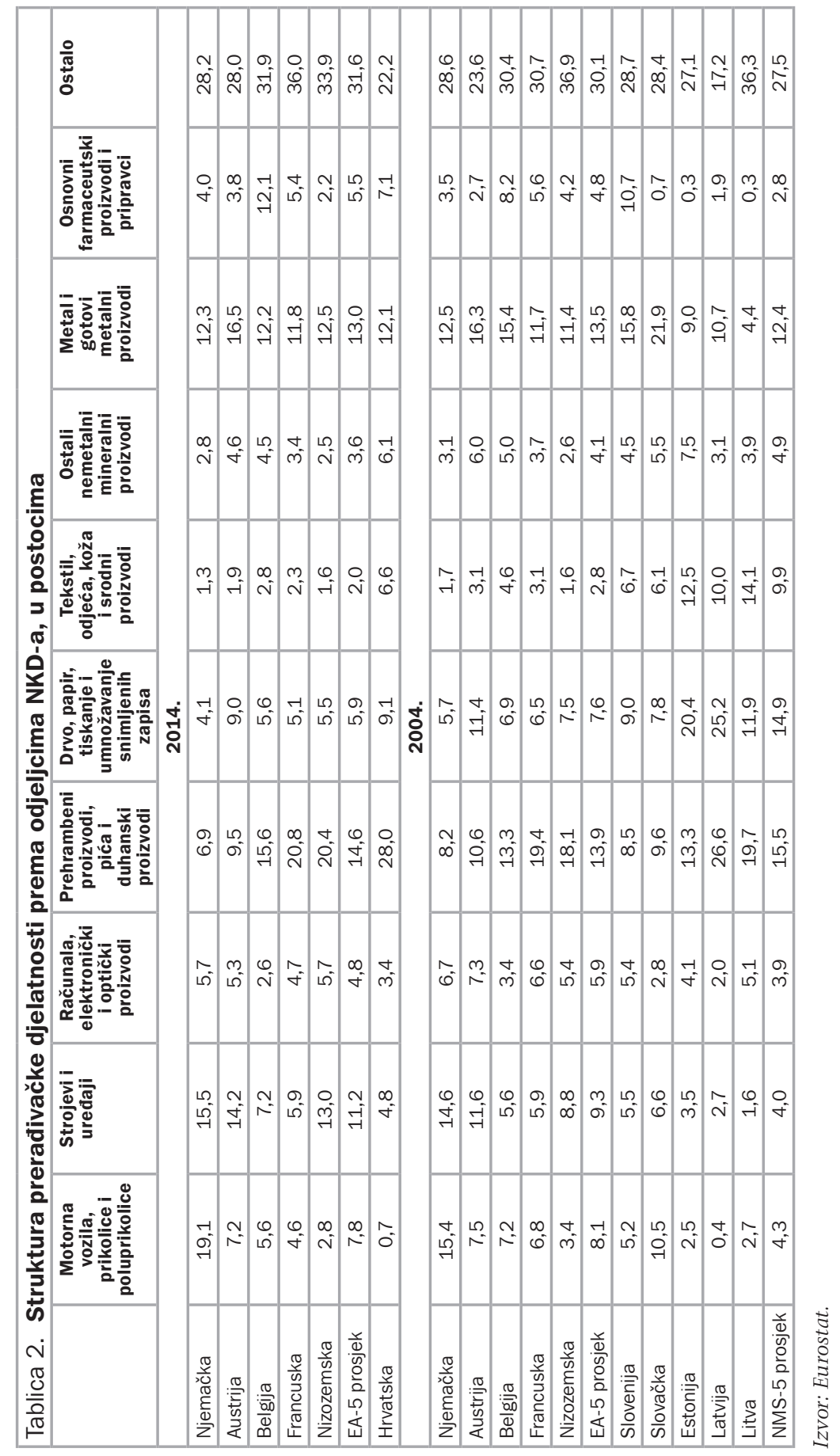


Kada bi se odluka donosila samo na osnovi kriterija diversificiranosti gospodarstva, vjerojatni zaključak bio bi taj da Hrvatska još nije potpuno spremna za uvođenje eura. Međutim, iako su reforme u smjeru otklanjanja prepreka za razvoj prerađivačke industrije i smanjenja relativne važnosti sektora turizma u nacionalnom gospodarstvu potrebne i poželine, takve prilagodbe se ne bi trebale smatrati preduvjetom za pristupanje Hrvatske monetarnoj uniji. Glavni je razlog to što bi Hrvatska kao mala, otvorena i visokoeuroizirana država i danas, dok još raspolaže samostalnom monetarnom politikom, mogla tu politiku tek u ograničenoj mjeri koristiti da stabilizira gospodarstvo u slučaju da negativan šok pogodi turizam ili neku drugu stratešku djelatnost. Stoga uvođenjem eura i prenošenjem monetarnog suvereniteta na Europsku središnju banku, Hrvatska neće biti ranjivija na asimetrične šokove nego što je danas. Štoviše, uvođenjem eura otpornost Hrvatske mogla bi se povećati jer će se time otkloniti rizik da asimetričan šok dovede do pritisaka na domaću valutu, a time i do valutne krize. Treba napomenuti i to da se struktura industrije Slovenije, Slovačke te, posebice, baltičkih država u trenutku njihova pristupanja tečajnom mehanizmu ${ }^{23}$ također razlikovala u odnosu na strukturu industrije članica europodručja (tablica 2).

\subsection{Mobilnost rada}

Mobilnost radne snage među hrvatskim regijama je relativno niska, što se ogleda u znatnim razlikama u stopama nezaposlenosti po županijama. Posljednjih nekoliko godina zamjećuje se intenzivna prekogranična mobilnost hrvatskih radnika potaknuta učincima dugotrajne krize te, posebice, njihovim lakšim pristupom tržištima rada razvijenih država članica nakon ulaska Hrvatske u EU 2013. godine. Naime, mobilnost faktora proizvodnje između Hrvatske i članica EU-a osigurana je u okviru jedinstvenog tržišta EU-a koje se zasniva na slobodnom kretanju robe, usluga, osoba i kapitala. U trenutku pristupanja Hrvatske EU-u nekoliko članica odlučilo je iskoristiti mogućnost dvogodišnje odgode primjene

\footnotetext{
${ }^{23}$ Godina u kojoj je država pristupila tečajnom mehanizmu uzima se kao referentno razdoblje zato što se ulazak u mehanizam može smatrati ključnim korakom o kojemu u velikoj mjeri ovisi ukupna dinamika i trajanje postupka uvođenja zajedničke valute.
} 
odredbi o slobodnom kretanju za radnike iz Hrvatske. Međutim, kako je samo manji broj tih država nakon isteka inicijalnoga dvogodišnjeg razdoblja odlučio zatražiti produljenje prijelaznog razdoblja, od sredine 2015. hrvatski radnici mogu bez radne dozvole participirati na tržištima rada većine drugih država članica. ${ }^{24}$ Mnogo hrvatskih državljana odlučilo je iskoristiti mogućnost zaposlenja u drugim članicama. Prema podacima Državnog zavoda za statistiku (DZS), 2014. i 2015. u druge članice EU-a emigriralo je više od 30 tisuća osoba. Međutim, zbog poteškoća u registraciji iseljavanja, smatra se da je intenzitet emigracije u službenoj statistici podcijenjen. ${ }^{25}$

U takvim okolnostima, može se reći da kriterij mobilnosti rada Hrvatska zadovoljava, ali zasad u manjoj mjeri. Iako je iseljavanje nezaposlenih radnika donekle smanjilo neravnoteže na domaćem tržištu rada tijekom dugotrajne recesije, u dugom bi roku odljev radnika, ako ne dođe do preokreta u migracijskim tokovima, mogao nepovoljno utjecati na potencijalni rast gospodarstva, ali i na održivost mirovinskog i zdravstvenog sustava. Trenutno nije moguće utvrditi je li odlazak radnika u inozemstvo posljednjih godina bio trajnoga karaktera ili će se znatan dio njih vratiti u zemlju kada se makroekonomski uvjeti poboljšaju. Ako se pokaže da je odljev radnika bio privremena pojava uzrokovana cikličkim činiteljima, onda bi se moglo reći da Hrvatska potpuno zadovoljava kriterij mobilnosti rada.

\subsection{Fleksibilnost cijena i plaća}

Iako se cijene u Hrvatskoj u normalnim uvjetima mijenjaju relativno sporo ${ }^{26}$, istraživanja pokazuju da se njihova fleksibilnost naniže osjetno povećava kada se poduzeća suoče sa znatnim smanjenjem potražnje. Naime, Pufnik

\footnotetext{
${ }^{24}$ Prijelazno ograničenje za hrvatske radnike u trenutku pristupanja Hrvatske EU-u odlučilo je primijeniti 13 članica: Njemačka, Austrija, Italija, Francuska, Belgija, Nizozemska, Luksemburg, Španjolska, Grčka, Cipar, Malta, Slovenija i Ujedinjeno Kraljevstvo. Od 1. srpnja 2015. ograničenje na mobilnost hrvatskih radnika primjenjuju još samo Austrija, Nizozemska, Malta, Slovenija i Ujedinjeno Kraljevstvo.

${ }^{25}$ Prema statistikama država u koje hrvatski radnici najviše iseljavaju, te su brojke znatno veće. Koristeći se tim izvorima, procjenjuje se da od ulaska Hrvatske u EU gubitak radne snage zbog negativnih neto migracija premašuje 100 tisuća osoba.

${ }^{26}$ Krznar (2011) pronalazi da u uobičajenim makroekonomskim uvjetima promjene cijena u Hrvatskoj prosječno nastupaju svakih osam tromjesečja, što upućuje na njihovu inertnost.
} 
i Kunovac (2012) na osnovi rezultata ankete provedene na uzorku od 295 hrvatskih poduzeća utvrđuju da se učestalost promjene cijena znatno povećava kada nastupi šok u obliku nagle promjene potražnje ili proizvodnih troškova. Primjerice, iako u normalnim okolnostima poduzeća svoje cijene mijenjaju rjeđe od jednom godišnje, u slučaju znatnog smanjenja potražnje prilagodba cijena nastupa već nakon jednog do tri mjeseca. Uspoređujući rezultate svoje analize s rezultatima sličnih istraživanja za europodručje, ovi autori zaključuju da je u Hrvatskoj fleksibilnost cijena u slučaju snažnih šokova relativno veća nego u članicama europodručja. Iz navedenog slijedi da Hrvatska u određenoj mjeri zadovoljava kriterij fleksibilnosti cijena.

Sličan zaključak može se donijeti i vezano uz kriterij fleksibilnosti plaća. Iako su nominalne plaće u Hrvatskoj prilično rigidne, u uvjetima duboke recesije koja je započela 2008. godine, poduzeća su nastojala smanjiti troškove rada, što se djelomično ostvarilo i zamrzavanjem odnosno smanjenjem nominalnih plaća. Naime, Kunovac i Pufnik (2015) na osnovi informacija prikupljenih anketom pokazuju da, iako je otpuštanje viška zaposlenih predstavljalo dominantnu strategiju prilagodbe poduzeća ${ }^{27}$, u kasnijoj fazi recesije, točnije u razdoblju od 2010. do 2013. godine, zamjetno se povećao broj poduzeća koja su posegnula za smanjenjem osnovne plaće. U Hrvatskoj je udio poduzeća koja su to napravila bio znatno veći u odnosu na prosječan udio u ostalim članicama koje su bile obuhvaćene anketom o dinamici plaća ${ }^{28}$ (26 u odnosu na 4,5 posto). Izquierdo i sur. (2017) pronalaze da se smanjenje osnovnih plaća u uvjetima krize događalo češće u državama u kojima je recesija bila izrazito snažna nego u državama gdje je gospodarski pad bio blag. Tako se, osim u Hrvatskoj, smanjenje nominalnih plaća učestalo primjenjivalo u baltičkim državama, Irskoj, Grčkoj i Cipru.

\footnotetext{
${ }^{27}$ U tom se smislu Hrvatska nije razlikovala od ostalih članica. Kako pokazuju Fabiani, Lamo, Messina i Room (2015), tijekom posljednje krize većina europskih poduzeća usredotočila se na smanjenje broja zaposlenih kako bi ostvarila potrebne uštede, a samo manji dio njih odlučio se na rezanje osnovne plaće.

${ }^{28}$ Wage Dynamics Network Survey (vidjeti više u Izquierdo i sur., 2017).
} 


\subsection{Fiskalna i politička integracija}

Stupanj fiskalne i političke povezanosti Hrvatske s europodručjem u velikoj mjeri ovisi o sadašnjem uređenju EMU-a te odgovara stupnju integracije ostalih članica koje još nisu uvele euro. Članstvom u EU-u Hrvatska je započela i svoje sudjelovanje u Europskom semestru kao godišnjem ciklusu koordinacije ekonomskih politika, s naglaskom na zdrave javne financije, $s$ jedne strane, te mjere za izbjegavanje akumulacije prekomjernih makroekonomskih neravnoteža i njihovo ispravljanje, s druge. Do uvođenja eura kao nacionalne valute, na Hrvatsku se ne odnose odredbe poput mogućnosti izravnih financijskih sankcija ${ }^{29} \mathrm{u}$ slučaju da ne provodi preporuke za ispravljanje prekomjernog manjka, kao ni odredbe o prethodnim konzultacijama s Europskom komisijom i drugim članicama EU-a pri donošenju novoga državnog proračuna.

Međutim, danas je Hrvatska u određenom smislu manje politički integrirana s ostalim članicama iako je nedavno pristupila Ugovoru o stabilnosti, koordinaciji i upravljanju u ekonomskoj i monetarnoj uniji, ali samo u jednom njegovom dijelu koji se odnosi na upravljanje EMU-om. Ugovor o stabilnosti, koordinaciji i upravljanju u ekonomskoj i monetarnoj uniji postavlja pravila za jaču koordinaciju ekonomskih politika i upravljanje europodručjem te posebno unaprjeđenje fiskalne discipline putem fiskalnog sporazuma koji je njegov sastavni dio. ${ }^{30}$ Potpisivanjem Ugovora prije uvođenja eura, članica EU-a pokazuje svoju spremnost na dublju integraciju. Unošenjem obveze poštivanja fiskalnih pravila iz Ugovora u Ustav ili drugi nacionalni propis sa snagom Ustava, država se

\footnotetext{
${ }^{29}$ Ipak, u slučaju pokretanja procedure pri prekomjernim makroekonomskim neravnotežama, slično kao i u slučaju nepoštivanja preporuke o ispravljanju prekomjernoga proračunskog manjka, Hrvatska je, kao članica koja još nije uvela euro, podložna sankcijama u obliku privremene suspenzije korištenja fondova EU-a.

${ }^{30}$ Ugovor se u potpunosti odnosi na članice europodručja, a mogu ga potpisati i članice koje još nisu uvele euro, te se u tom slučaju na njih ne odnosi dio odredbi, osim ako same to ranije ne zatraže. Članice koje se nalaze izvan europodručja imaju pravo izuzeća od primjene pojedinih poglavlia Ugovora. Navedeno se posebno odnosi na obveze iz glave III. (fiskalni ugovor) te glave IV. (koordinacija ekonomskih politika i konvergencija). Dosad su taj Ugovor potpisale sve države članice osim Ujedinjenog Kraljevstva i Češke. Hrvatska je u siječnju 2018. pristupila Ugovoru i to na način da preuzima obveze koje proistječu iz glave V., a koje se odnose na sudjelovanje na sastancima na vrhu država europodručja, koji će se održavati najmanje dva puta godišnje i na kojima će se raspravljati o konkurentnosti članica, izmjenama i novim pravilima koja će se primjenjivati na europodručje u budućnosti, kao i o specifičnim pitanjima koja se odnose na provedbu Ugovora o stabilnosti, koordinaciji i upravljanju.
} 
dodatno obvezuje na fiskalnu disciplinu kakvu zahtijeva (buduća potpuna) ekonomska i monetarna unija.

Istovremeno, Hrvatska je kao članica EU-a u prilici dati podršku nastojanjima čelnika institucija $E U-a^{31}$ da se sadašnja ekonomska i monetarna unija upotpuni nekim oblikom fiskalne unije. Dok traju rasprave o kojem bi obliku makroekonomske stabilizacijske funkcije za europodručje bila riječ, a uglavnom se misli na neke ograničene oblike fiskalne integracije (primjerice, zajednička shema osiguranja za nezaposlene ili zajednički fond za ulaganja), neka su načela i preduvjeti za bilo koji oblik fiskalnoga kapaciteta poznati. To su izbjegavanje moralnog hazarda, dosljedna primjena fiskalnih pravila i uklanjanje strukturnih slabosti. Nadalje, kao preduvjete za takvu mjeru daljnje integracije, posebno treba izdvojiti spremnost članica na dublju političku integraciju i visok stupanj prethodno izgrađenog povjerenja u sposobnost okvira za upravljanje da uspješno koordinira fiskalne politike u EMU-u i u nacionalne vlade da će poštivati pravila tog okvira.

\subsection{Zašto teorija optimalnih valutnih područja nije sasvim relevantna za Hrvatsku}

Hrvatska ne mora nužno zadovoljiti sve kriterije teorije optimalnih valutnih područja da bi profitirala uvođenjem eura. Kako je primijetio Tavlas (1994), velika je manjkavost teorije optimalnih valutnih područja to što njezini kriteriji često upućuju na oprečne zaključke o opravdanosti pristupanja neke države valutnom području. Primjerice, u slučaju Hrvatske teorija optimalnih valutnih područja ne daje odgovor na pitanje jesu li usklađenost poslovnih ciklusa i visok stupanj trgovinske i financijske integracije dovoljno snažni argumenti u korist uvođenja eura, tako da se uvođenje eura Hrvatskoj isplati unatoč rigidnosti nominalnih plaća i nedovoljnoj diversificiranosti gospodarstva. S obzirom na taj značajan

\footnotetext{
${ }^{31}$ Misli se prvenstveno na Izvješće petorice predsjednika iz 2015. koje navodi potrebne korake za dovršetak europske ekonomske i monetarne unije, među kojima se nalaze i mjere za uspostavljanje fiskalne i političke unije. Sve članice su konzultirane u postupku izrade tog izvješća, a također sudjeluju u pregovorima oko pojedinih inicijativa koje iz njega proistječu i predstavljene su kao legislativni prijedlozi.
} 
nedostatak, teorija optimalnih valutnih područja može biti korisna kao konceptualni okvir za promišljanje o spremnosti države za članstvo u monetarnoj uniji, ali ona nikako ne može biti jedino mjerilo na kojemu će se odluka o pristupanju monetarnoj uniji temeljiti.

Nadalje, teorija optimalnih valutnih područja precjenjuje doseg monetarne politike u malim otvorenim gospodarstvima. Kako je istaknuto ranije, teorija optimalnih valutnih područja nastala je 1960-ih godina, kada su globalni kapitalni tokovi bili slabi, što je središnjim bankama osiguravalo prostor za aktivno vođenje monetarne politike. $U$ današnje vrijeme, u uvjetima intenzivnih međunarodnih kapitalnih tokova, središnje banke malih država prisiljene su usklađivati se s politikama ključnih svjetskih središnjih banaka, poglavito Europske središnje banke i američkog Sustava federalnih rezervi (Fed), kako bi se zaštitile od špekulativnih tokova kapitala. Stoga je manevarski prostor za diskrecijsko vođenje monetarne politike u malim državama znatno sužen.

Iz hrvatske perspektive posebno je velik nedostatak teorije to što ona zanemaruje činjenicu da izloženost valutnom riziku za neke države može biti ključan argument u korist pristupanja monetarnoj uniji. Ako su gospodarski subjekti u nekoj državi visoko zaduženi u stranoj valuti, kolebanje tečaja izravno se prenosi na trošak otplate duga, a time i na raspoloživi dohodak i gospodarsku aktivnost. Uvođenjem valute uz koju su vezane obveze domaćih subjekata ta bi država trenutačno otklonila valutni rizik, što bi donijelo veliku korist ukupnom gospodarstvu. Istodobno, trošak pristupanja monetarnoj uniji u smislu gubitka samostalne monetarne politike za takve je države relativno mali jer je fleksibilnost monetarne politike ionako niska zbog potrebe za očuvanjem stabilnosti tečaja. Ta ograničenja posebno se očituju u razdobljima financijskih i gospodarskih poremećaja. Naime, kako su istaknuli Galac i Kraft (2012), središnja banka u maloj, otvorenoj i visokoeuroiziranoj državi nalazi se pred ozbiljnom dilemom kada je istodobno suočena s gospodarskim padom i deprecijacijskim pritiscima na valutu. S jedne strane, ako središnja banka odluči braniti stabilan nominalni tečaj, to će iziskivati restriktivne mjere monetarne politike koje mogu dodatno produbiti recesiju. $\mathrm{S}$ druge strane, $\mathrm{u}$ 
slučaju da središnja banka odluči da neće intervenirati na deviznom tržištu, deprecijacija tečaja domaće valute otežat će financijski položaj subjekata čiji je dug vezan uz stranu valutu, što također može djelovati prorecesijski.

Podaci o valutnoj strukturi duga domaćih sektora prikazani na slici 9 razotkrivaju znatnu izloženost hrvatskoga gospodarstva valutnom riziku. Malo više od tri četvrtine ukupnog duga opće države i duga nefinancijskih poduzeća te približno 60 posto duga stanovništva nominirano je u stranoj valuti ili je vezano uz stranu valutu. Visok postotak deviznog duga u ukupnom dugu domaćih sektora posljedica je znatne inozemne zaduženosti gospodarstva i visokog stupnja euroizacije bankovnih kredita. Specifičnost hrvatskoga bankovnog sustava visok je udio devizne štednje kućanstava u ukupnim izvorima financiranja banaka, a to nadalje potiče banke da plasiranjem indeksiranih kredita minimiziraju direktnu izloženost valutnom riziku. Međutim, praksa odobravanja kredita s valutnom klauzulom zajmoprimce izlaže valutnom riziku, a to posredno povećava i rizike za bankovni sustav (Šošić i Kraft, 2006). Naime, odobravanjem kredita indeksiranih uz stranu valutu osobama koje prihode ostvaruju u domaćoj valuti, banke se izlažu valutno induciranom kreditnom riziku, odnosno riziku da će dužnici u slučaju deprecijacije i posljedičnog povećanja anuiteta prestati uredno podmirivati svoje obveze.

Galac i Kraft (2012) utvrđuju da se u razdoblju od 2002. do 2007. udio deviznih depozita i kredita u ukupnim depozitima i kreditima hrvatskih banaka kontinuirano smanjivao, što je rezultat mjera prudencijalne politike središnje banke. Naime, Hrvatska narodna banka tada je primjenjivala različite mjere kako bi smanjila rizike za financijsku stabilnost, a jedan od učinaka tih mjera bilo je povećanje efektivnog troška poslovanja s deviznim depozitima i kreditima za banke. U takvim uvjetima banke počinju intenzivnije promovirati "čiste" kunske depozite i kredite, što se odrazilo u postupnom rastu udjela kunskih u ukupnim depozitima i kreditima. Međutim, izbijanjem krize u jesen 2008. povećala se neizvjesnost, a time i preferencija hrvatskih građana za deviznim depozitima, pa se euroizacija depozita i kredita ubrzo vratila na visoku početnu razinu. Ivanov, Tkalec i Vizek (2011) ističu da se sličan uzorak kretanja euroizacije (dolarizacije), pri 
čemu se stupanj euroizacije pod utjecajem makroekonomske nestabilnosti naglo povećava i potom ostaje na visokim razinama, zamjećuje i u drugim euroiziranim državama. S obzirom na to da se stupanj euroizacije u slučaju snažnih šokova u pravilu prilagođava asimetrično, ove autorice smatraju da se kretanje euroizacije ne može vierodostojno obuhvatiti linearnim ekonometrijskim modelima, pa stoga u svojoj studiji primjenjuju i modele praga (threshold models).

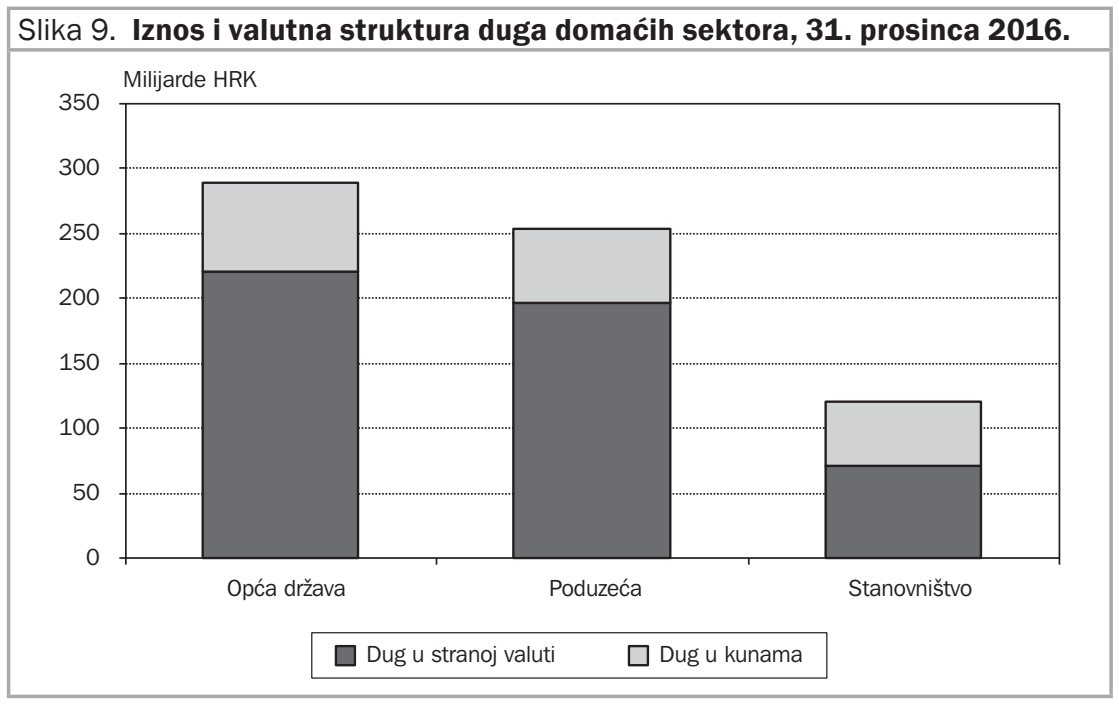

Izvori: HNB i Hanfa.

S obzirom na visok iznos duga u stranoj valuti, nije teško predvidjeti da bi znatnija deprecijacija kune prema euru imala izražen negativan učinak na bilance domaćih sektora. Ako se uzme u obzir činjenica da bruto devizni dug domaćih sektora iznosi 511 milijardi kuna (148 posto BDP-a), nominalna deprecijacija kune prema euru od 10 posto trenutačno bi povećala glavnicu duga za 51 milijardu kuna, odnosno za približno 15 posto BDP-a. Rast glavnice duga izravno bi doveo do povećanja troška njegove otplate, a time i do smanjenja raspoloživog dohotka dužnika. S obzirom na to da samo manji dio dužnika posjeduje prirodnu zaštitu od valutnog rizika - u obliku devizne imovine ili deviznih prihoda - negativan 
učinak deprecijacije tečaja na raspoloživi dohodak bio bi prisutan kod većine zaduženih subjekata. ${ }^{32}$ Slabljenje kune osobito bi se negativno odrazilo na stabilnost javnih financija. Naime, u scenariju 10-postotne deprecijacije kune dug opće države porastao bi za 22 milijarde kuna, odnosno za 6,4 posto BDP-a, dok bi izravan negativan učinak na proračun iznosio gotovo 1 milijardu kuna na godišnjoj razini. ${ }^{33} \mathrm{Uz}$ spomenute izravne učinke na razinu duga i proračun, dodatan problem bilo bi smanjenje vjerodostojnosti države na financijskim tržištima. Naime, u razdoblju nakon deprecijacije kune investitori bi zahtijevali višu premiju za rizik kako bi se zaštitili od mogućega daljnjeg slabljenja kune, ali i od negativnih učinaka inicijalne deprecijacije tečaja na visokoeuroizirano domaće gospodarstvo. U takvim uvjetima, nova zaduženja bila bi moguća jedino uz viši kamatni trošak, s negativnim učincima na proračunski saldo.

Eventualno slabljenje kune, osim što bi negativno djelovalo na bilance dužnika, moglo bi prouzročiti još neke nepoželine makroekonomske pojave (Kraft, 2003). Primjerice, deprecijacija tečaja kune vjerojatno bi potaknula gospodarske subjekte da svoje kunske depozite i gotovinu konvertiraju u euro kako bi se zaštitili od mogućeg nastavka trenda slabljenja domaće valute. Takva povećana potražnja za stranom valutom dodatno bi pridonijela deprecijacijskim pritiscima na kunu. Također, izvjesno je da bi deprecijacija tečaja putem porasta cijena uvoznih proizvoda rezultirala povećanjem stope inflacije. S obzirom na uvoznu ovisnost hrvatskog gospodarstva, a time i značajan utjecaj cijena uvoznih dobara na ukupnu dinamiku cijena u zemlji, politika relativno stabilnog tečaja kune prema euru već dugi niz godina služi kao glavno sidro inflacijskih očekivanja u Hrvatskoj. Iznenadnom deprecijacijom tečaja kredibilitet tog sidra bio bi nepovratno izgubljen, što bi umanjilo sposobnost središnje banke da i nadalje uspješno održava nisku inflaciju.

\footnotetext{
${ }_{32}$ Primjerice, prema podacima za kraj 2016. čak 86 posto deviznih kredita stanovništvu i poduzećima nije bilo zaštićeno od valutno induciranog kreditnog rizika (HNB, 2017).

${ }^{33}$ U 2016. implicitna kamatna stopa na ukupan javni dug (kunski i devizni) iznosila je 3,9 posto. Uz pretpostavku da jednako toliko iznosi kamatna stopa na devizni dio javnog duga, povećanje glavnice deviznog duga od 22 milijarde kuna dovelo bi do porasta godišnjih kamatnih izdataka za otprilike 850 milijuna kuna.
} 
Treba napomenuti da želja za eliminiranjem valutnog rizika ne može biti jedini argument za pristupanje monetarnoj uniji, pa tako ni u slučaju Hrvatske. Država mora biti dovoljno integrirana s članicama monetarne unije da bi joj fiksan devizni tečaj i zajednička monetarna politika odgovarali. Neugodno iskustvo nekoliko država Latinske Amerike koje su fiksirale tečajeve svojih valuta u odnosu na američki dolar, a potom bile suočene s financijskom krizom podsjeća koliko monetarno integriranje može biti opasno ako prije toga nije dosegnut dovoljno visok stupanj ekonomske integracije. ${ }^{34}$ Međutim, analiza predstavljena u ovom radu pokazala je da je hrvatsko gospodarstvo trgovinski i financijski snažno integrirano s europodručjem, pa nije vjerojatno da će se nakon uvođenja eura sličan scenarij dogoditi u Hrvatskoj. Visok stupanj ekonomske integriranosti s europodručjem i znatan eurski dug domaćih sektora vrlo su snažni argumenti u korist uvođenja eura u Hrvatskoj.

\section{Zaključak}

Teorija optimalnih valutnih područja predlaže nekoliko kriterija koje bi država trebala zadovoljiti da bi mogla uspješno funkcionirati u uvjetima zajedničke monetarne politike. Većina kriterija odnosi se na utvrđivanje stupnja ekonomske integracije između države i monetarne unije, s obzirom na to da snažna ekonomska integriranost implicira manji rizik asimetričnih šokova. Preciznije, teorija optimalnih valutnih područja upućuje na to da je pristupanje monetarnoj uniji razuman korak za državu ako ona s članicama monetarne unije ostvaruje intenzivne vanjskotrgovinske i financijske odnose te visoku korelaciju poslovnih ciklusa, ako između njih postoji mobilnost rada te ako su nominalne cijene i plaće u državi dovoljno fleksibilne da bi joj omogućile prilagodbu u slučaju asimetričnog šoka. Nadalje, struktura gospodarstva trebala bi biti diversificirana kako država ne

\footnotetext{
${ }_{34}$ Primjerice, Argentina je 1991. počela primjenjivati režim valutnog odbora temeljen na američkom dolaru. U tom trenutku razmjena Argentine s SAD-om činila je 14 posto njene ukupne vanjskotrgovinske razmjene, približno jednako kao razmjena s Brazilom (15 posto), dok je udio razmjene s članicama EU-a bio gotovo dvostruko viši (27 posto). Deprecijacija brazilskog reala i istodobna aprecijacija američkog dolara (a usporedno s time i argentinskog pesa) krajem 1990-ih negativno su se odrazili na cjenovnu konkurentnost Argentine, što je produbilo recesiju i pridonijelo izbijanju financijske krize 2001. godine (Međunarodni monetarni fond, 2003).
} 
bi bila prekomjerno osjetljiva na šokove koji pogađaju pojedinačne sektore. Naposljetku, poželjno je da između države i ostalih članica monetarne unije postoji odgovarajuća politička integracija koja će biti jamstvo koordinacije u području ostalih ekonomskih politika te fiskalna integracija u smislu postojanja fiskalnih transfera namijenjenih državama koje su pogođene negativnim šokom. Ako država navedene uvjete ne ispunjava, ona bi trebala zadržati monetarnu neovisnost, jer bi u suprotnome mogla biti izložena asimetričnim šokovima koje neće moći adekvatno amortizirati.

Kriteriji koji govore u prilog uvođenju eura u Hrvatskoj su trgovinska i financijska integracija, usklađenost poslovnih ciklusa te politička integracija. Gotovo dvije trećine ukupne međunarodne razmjene Hrvatska ostvaruje s članicama europodručja te je prema tom pokazatelju snažnije integrirana od nekih postojećih članica monetarne unije. Pristupanjem Hrvatske EU-u 2013. godine uklonjene su preostale prepreke slobodnom kretanju robe i usluga, što je pridonijelo dodatnom zamjetnom jačanju vanjskotrgovinske razmjene s europodručjem. Osim trgovinske integracije, Hrvatsku karakterizira i visok intenzitet financijskih odnosa s članicama europodručja, što ponajprije proizlazi iz znatne participacije banaka iz europodručja u hrvatskom bankovnom sustavu. Recentno istraživanje koje su proveli Kotarac i sur. (2017) pokazalo je da između Hrvatske i europodručja postoji visok stupanj usklađenosti poslovnih ciklusa. Ista studija pokazala je da na domaću gospodarsku aktivnost dominantno utječu simetrični šokovi, dakle oni šokovi koji imaju usporediv učinak na gospodarsku aktivnost u Hrvatskoj i europodručju. Uzimajući u obzir visok stupanj usklađenosti ciklusa i dominaciju simetričnih šokova, može se zaključiti da bi Hrvatska nakon uvođenja eura mogla bez poteškoća funkcionirati u uvjetima zajedničke monetarne politike. Naposljetku, ulaskom u EU Hrvatska je započela svoje sudjelovanje u Europskom semestru - mehanizmu za koordinaciju ekonomskih politika, čime se povećao stupanj političke integracije s članicama europodručja, a uvođenjem eura preuzet će i obvezu poštivanja strožih fiskalnih pravila. Pod pretpostavkom da će navedeni mehanizmi biti jamstvo discipline nositelja ekonomskih politika te da će makroprudencijalna politika biti djelotvorna 
u ublažavanju sistemskih financijskih rizika, vjerojatnost novih dubokih kriza u Hrvatskoj i EMU-u trebala bi biti manja nego u prošlosti.

Slabe rezultate Hrvatska ostvaruje kada je riječ o kriteriju diversificiranosti gospodarstva. Nedovoljna diversificiranost hrvatskoga gospodarstva najbolje se prepoznaje u prekomjernoj ovisnosti o sektoru turizma. Prema relativnoj veličini prihoda od turizma Hrvatska odskače čak i u odnosu na druge mediteranske turističke države poput Grčke, Portugala i Španjolske. Višak koji Hrvatska ostvaruje u razmjeni usluga - za što je gotovo u cijelosti zaslužan sektor turizma - veći je od strukturnog manjka u robnoj razmjeni, pa tako Hrvatska u posljednje vrijeme postiže pozitivan saldo na tekućem računu platne bilance. Međutim, takva struktura salda na tekućem računu velik je izvor ranjivosti. Naime, kad bi se pod utjecajem vanjskog šoka prihodi sektora turizma zamjetno smanjili, izvjesno je da bi došlo do pogoršanja salda na tekućem računu, što bi u slučaju izostanka snažnijih priljeva na financijskom računu izazvalo poremećaje na deviznom tržištu, s mogućim deprecijacijskim pritiscima na domaću valutu. Stoga, kad bi se odluka donosila samo na osnovi kriterija diversificiranosti gospodarstva, vjerojatni bi zaključak bio da Hrvatska još nije potpuno spremna za uvođenje eura. Međutim, iako su reforme u smjeru uklanjanja prepreka za razvoj prerađivačke industrije i smanjivanja relativne važnosti sektora turizma u nacionalnom gospodarstvu potrebne i poželine, takva prilagodba gospodarstva ne bi se trebala smatrati preduvjetom za pristupanje Hrvatske monetarnoj uniji. Glavni je razlog to što Hrvatska kao mala, otvorena i visokoeuroizirana država niti danas ne bi mogla aktivno provoditi monetarnu i tečajnu politiku stabilizacije gospodarstva u slučaju da negativan šok pogodi turizam ili neku drugu stratešku djelatnost. Stoga uvođenjem eura i prenošenjem monetarnog suvereniteta na Europsku središnju banku, Hrvatska neće biti ranjivija na asimetrične šokove nego što je danas. Štoviše, uvođenjem eura otpornost Hrvatske mogla bi se povećati jer će se time otkloniti rizik da u slučaju asimetričnog šoka dođe do pritisaka na domaću valutu, a time i do valutne krize.

Teorija optimalnih valutnih područja ima određene nedostatke zbog kojih ona ne može imati presudnu ulogu kada se ocjenjuje primjerenost eura za 
Hrvatsku. Najveći nedostatak je to što njeni kriteriji često daju oprečne rezultate, pa striktnom primjenom teorije u pravilu nije moguće donijeti odluku o tome je li neka država spremna za pristupanje monetarnoj uniji. Drugim riječima, teorija optimalnih valutnih područja u mnogo slučajeva jednostavno ne daje tražene odgovore. Primjerice, u slučaju Hrvatske ta teorija ne daje odgovor na pitanje jesu li visoka usklađenost poslovnih ciklusa te snažna trgovinska i financijska integracija s europodručjem dovoljno snažni argumenti u korist uvođenja eura, unatoč slaboj diversificiranosti hrvatskog gospodarstva. Zbog toga, analiza opravdanosti pristupanja monetarnoj uniji ne može se zasnivati samo na ocjeni ispunjavanja kriterija teorije optimalnih valutnih područja, već mora uključivati i detaljnu kvantifikaciju svih potencijalnih prednosti i nedostataka članstva u takvoj uniji, pritom uzimajući u obzir ekonomske specifičnosti države kandidatkinje.

Drugi nedostatak teorije je to što ona precjenjuje važnost monetarne i tečajne politike kao instrumenata stabilizacije u malim i otvorenim državama. U uvjetima liberaliziranih međunarodnih tokova kapitala, središnje banke malih država prisiljene su usklađivati se s politikama središnjih banaka najvećih gospodarstava ako žele izbjeći špekulativne kapitalne tokove koji mogu ugroziti financijsku stabilnost. Zbog toga male države pri vođenju monetarne politike imaju znatno uži manevarski prostor nego velike države, pa ulaskom u monetarnu uniju i odricanjem od samostalne monetarne politike one u pravilu ne gube mnogo. Teorija optimalnih valutnih područja tu činjenicu ne uzima u obzir.

Iz perspektive Hrvatske velik nedostatak teorije je i to što ona potpuno zanemaruje pitanje valutnog rizika. Visoka zaduženost domaćih gospodarskih subjekata u eurima značajan je izvor ranjivosti hrvatskog gospodarstva. U slučaju izraženijeg slabljenja kune prema euru pogoršao bi se financijski položaj svih domaćih sektora, a negativni učinci posebice bi se očitovali u javnim financijama. Hrvatski javni dug iznosi približno 290 milijardi kuna (84 posto BDP-a), a više od tri četvrtine tog iznosa vezano je uz euro. Iz toga proizlazi da bi izraženija deprecijacija kune prema euru izazvala snažan porast glavnice javnog duga, a time i proračunskih 
izdataka za njegovu otplatu. Osim toga, deprecijacija tečaja smanjila bi vjerodostojnost Hrvatske na financijskim tržištima te bi tako otežala i poskupjela refinanciranje visokoga javnog duga. Financijske institucije nastoje održavati uravnotežene devizne pozicije pa nisu izravno izložene valutnom riziku. Međutim, one su valutnom riziku izložene posrednim putem jer je značajan postotak plasmana nefinancijskom sektoru odobren uz valutnu klauzulu. Eventualno slabljenje tečaja kune dovelo bi do materijalizacije valutno induciranog kreditnog rizika - dio dužnika ne bi mogao podmirivati povećane anuitete svojih kredita, što bi bankama nanijelo gubitke. Stoga, uvođenjem eura i otklanjanjem valutnog rizika profitirao bi i financijski i nefinancijski sektor. Istodobno, prepuštanje monetarne politike Europskoj središnjoj banci za Hrvatsku ne bi trebao biti velik problem. Djelujući unutar zadanih ograničenja, ponajprije visoke euroiziranosti gospodarstva, HNB je u provedbi monetarne politike primarno usredotočen na očuvanje stabilnosti tečaja. U takvim uvjetima, stupanj fleksibilnosti monetarne politike već je sada prilično nizak, pa uvođenjem eura Hrvatska u biti neće izgubiti važnu polugu ukupne ekonomske politike. 
Ahearne, A., von Hagen, J. i Schmitz, B. (2007). Current account imbalances in the euro area. U A. Aslund i M. Dabrowski (Ur.), Challenges of globalization: Imbalances and growth (str. 41-57). Washington, DC: Peterson Institute for International Economics.

Allard, C., Koeva Brooks, P., Bluedorn, J. C., Bornhorst, F., Christopherson, K., Ohnsorge, F. i Poghosyan, T. (2013). Toward a fiscal union for the euro area. IMF Staff Discussion Notes No. 13/09. doi: https://doi. org/10.5089/9781484307373.006

Arčabić, V. (2011). Usklađenost poslovnih ciklusa Republike Hrvatske sa zemljama Europske unije. Zbornik Ekonomskog fakulteta u Zagrebu, 9(1), $127-144$.

Banco de Espana. (2010). Annual report 2009. Dostupno na: https:// www.bde.es/f/webbde/Secciones/Publicaciones/PublicacionesAnuales/ InformeAnual/inf2009e.pdf

Bayoumi, T. i Eichengreen, B. (1992). Shocking aspects of European monetary unification. NBER Working Papers No. 3949. doi: https://doi. org/10.3386/w3949

Beblavý, M., Marconi, G. i Maselli, I. (2015). A European unemployment benefit scheme: The rationale and the challenges ahead. Luxembourg i Bruxelles: Publications Office of the European Union i Centre for European Policy Studies.

Belullo, A., Šonje, V. i Vrbanc, I. (2000). Je li Srednja Europa optimalno valutno područje? Istraživanja HNB-a br. 8. Zagreb: Hrvatska narodna banka.

Blanchard, O. i Giavazzi, F. (2002). Current account deficits in the euro area: The end of the Feldstein-Horioka puzzle? Brookings Papers on Economic Activity, 33(2), 147-210. doi: https://doi.org/10.1353/eca.2003.0001 
Bonin, H., Eichhorst, W., Florman, C., Okkels Hansen, M., Skiold, L., Stuhler, J., Tatsiramos, K., Thomasen, H. i Zimmermann, K. F. (2008). Geographic mobility in the European Union: Optimising its economic and social benefits. IZA Research Reports No. 19. Bonn: Institute for the Study of Labor.

Bordo, M. D. (1993). The Bretton Woods international monetary system: A historical overview. U M. D. Bordo i B. Eichengreen (Ur.), A retrospective on the Bretton Woods system: Lessons for international monetary reform (str. 3-108). Chicago, IL: University of Chicago Press. doi: https://doi. org/10.7208/chicago/9780226066905.001.0001

Brkić, M. i Šabić, A. (2014). Okvir za praćenje makroekonomskih neravnoteža u Europskoj uniji - značenje za Hrvatsku. Pregledi HNB-a br. 25. Zagreb: Hrvatska narodna banka.

Broz, T. (2005). Teorija optimalnih valutnih područja: pregled literature. Privredna kretanja i ekonomska politika, 15(104), 52-78.

Broz, T. (2008). The introduction of the euro in Central and Eastern European countries - Is it economically justifiable? Radni materijali EIZ-a br. 0801. Zagreb: Ekonomski institut, Zagreb.

Buiter, W. H., Corsetti, G. M. i Pesenti, P. A. (1998). Interpreting the ERM crisis: Country-specific and systemic issues. Princeton Studies in International Finance No. 84. Princeton, NJ: Princeton University.

Buiter, W. H. i Sibert, A. C. (2005). How the eurosystem's treatment of collateral in its open market operations weakens fiscal discipline in the eurozone (and what to do about it). CEPR Discussion Paper No. 5387. London: Centre for Economic Policy Research.

Campa, J. M. i Gavilan, A. (2006). Current accounts in the euro area: An intertemporal approach. Banco de Espana Working Papers No. 0638. 
Ca'Zorzi, M. i Rubaszek, M. (2008). On the empirical evidence of the intertemporal current account model for the euro area countries. $E C B$ Working Papers No. 895.

Central Bank of Ireland. (2007). Quarterly bulletin 4. Dostupno na: https:// www.centralbank.ie/docs/default-source/publications/quarterly-bulletins/ qb-archive/2007/2007-no--4-economic-commentary.pdf?sfvrsn=6

Committee for the Study of Economic and Monetary Union. (1989). Report on economic and monetary union in the European Community. Luxembourg: Publications Office of the European Communities.

Darvas, Z. i Szapary, G. (2008). Business cycle synchronization in the enlarged EU. Open Economies Review, 19(1), 1-19. doi: https://doi. org/10.1007/s11079-007-9027-7

De Grauwe, P. i Mongelli, F. P. (2005). Endogeneities of optimum currency areas: What brings countries sharing a single currency closer together? ECB Working Papers No. 468.

Derado, D. (2009). Financial integration and financial crisis: Croatia approaching the EMU. Financial Theory and Practice, 33(3), 299-328.

Ehrmann, M., Fratzscher, M., Gürkaynak, R. S. i Swanson, E. T. (2007). Convergence and anchoring of yield curves in the euro area. ECB Working Papers No. 817.

Eichengreen, B. (2000). The ERM crisis in retrospect. NBER Working Papers No. 8035.

Eichengreen, B., Hausmann, R. i Panizza, U. (2003). Currency mismatches, debt intolerance and original sin: Why they are not the same and why it matters. NBER Working Papers No. 10036. doi: https://doi.org/10.3386/ w10036 
Europska komisija. (1990). One market, one money: An evaluation of the potential benefits and costs of forming an economic and monetary union. Bruxelles: European Commission.

Europska komisija. (2014). Recent trends in the geographical mobility of workers in the EU [Supplement to the EU Employment and Social Situation Quarterly Review]. Bruxelles: European Commission.

Europski mehanizam za stabilnost. (2016). Annual report 2015. Luxembourg: Publications Office of the European Union.

Europski odbor za sistemske rizike. (2014a). Flagship report on macroprudential policy in the banking sector. Frankfurt: European Systemic Risk Board.

Europski odbor za sistemske rizike. (2014b). The ESRB handbook on operationalising macro-prudential policy in the banking sector. Frankfurt: European Systemic Risk Board.

Fabiani, S., Lamo, A., Messina, J. i Room, T. (2015). European firm adjustment during times of economic crisis. ECB Working Papers No. 1778. doi: https://doi.org/10.1186/s40173-015-0048-3

Fidrmuc, J. (2004). The endogeneity of the optimal currency area criteria, intra-industry trade, and EMU enlargement. Contemporary Economic Policy, 22(1), 1-12. doi: https://doi.org/10.1093/cep/byh001

Frankel, J. A. i Rose, A. K. (1998). The endogeneity of the optimum currency area criteria. Economic Journal, 108(449), 1009-1025. doi: https://doi. org/10.1111/1468-0297.00327

Friedman, M. (1953). The case for flexible exchange rates. U M. Friedman (Ur.), Essays in positive economics (str. 157-203). Chicago, IL: University of Chicago Press.

Furceri, D. i Karras, G. (2008). Business-cycle synchronization in the EMU. Applied Economics, 40(12), 1491-1501. doi: https://doi. org/10.1080/00036840600843954

64 Je li euro optimalna valuta za Hrvatsku: ocjena korištenjem teorije optimalnih valutnih područja 
Galac, T. i Kraft, E. (2012). Monetary and financial policies for de-euroization: A case study of recent Croatian experience. Comparative Economic Studies, 54(3), 443-470. doi: https://doi.org/10.1057/ces.2012.23

Garber, P. M. (1993). The collapse of the Bretton Woods fixed exchange rate system. U M. D. Bordo i B. Eichengreen (Ur.), A retrospective on the Bretton Woods system: Lessons for international monetary reform (str. 461-494). Chicago, IL: University of Chicago Press.

Globan, T. (2014). Testing the "trilemma" in post-transition Europe - A new empirical measure of capital mobility. Post-Communist Economies, 26(4), 459-476. doi: https://doi.org/10.1080/14631377.2014.964459

Globan, T. (2015). From financial integration to sudden stops? New evidence from EU transition countries. Czech Journal of Economics and Finance, 65(4), 336-359.

Globan, T. i Sorić, P. (2017). Financial integration before and after the crisis: Euler equations (re)visit the European Union. EFZG Working Paper Series br. 17-02. Zagreb: Ekonomski fakultet Sveučilišta u Zagrebu.

Gogas, P. (2013). Business cycle synchronisation in the European Union: The effect of the common currency. Journal of Business Cycle Measurement and Analysis, 2013(1), 1-14. doi: https://doi.org/10.1787/jbcma-20135k43jt540lzs

Gros, D. (2011, November 9). What is holding Italy back? VoxEU.org [CEPR's policy portal]. Dostupno na: https://voxeu.org/article/what-holdingitaly-back

Gros, D. (2012). Macroeconomic imbalances in the euro area: Symptom or cause of the crisis? CEPS Policy Brief No. 266. Bruxelles: Centre for European Policy Studies.

Hale, G. i Obstfeld, M. (2014). The euro and the geography of international debt flows. Federal Reserve Bank of San Francisco Working Paper No. 201410. doi: https://doi.org/10.24148/wp2014-10 
Hausmann, R., Panizza, U. i Stein, E. (2001). Why do countries float the way they float? Journal of Development Economics, 66(2), 387-414. doi: https://doi.org/10.1016/S0304-3878(01)00168-7

Higgins, B. (1993). Was the ERM crisis inevitable? Federal Reserve Bank of Kansas City Economic Review, 78(4), 27-40.

Holinski, N., Kool, C. i Muysken, J. (2012). Persistent macroeconomic imbalances in the euro area: Causes and consequences. Federal Reserve Bank of St. Louis Review, 94(1), 1-20. doi: https://doi.org/10.20955/r.94.1-20

Horwath, R. i Komarek, L. (2002). Optimum currency area theory: An approach for thinking about monetary integration. Warwick Economic Research Papers No. 647. Coventry: University of Warwick.

Hrvatska narodna banka (HNB). (2016). Bilten br. 226. Zagreb: Hrvatska narodna banka.

Hrvatska narodna banka (HNB). (2017). Financijska stabilnost br. 18. Zagreb: Hrvatska narodna banka.

Ingram, J. C. (1962). Regional payments mechanisms: The case of Puerto Rico. Chapel Hill, NC: University of North Carolina Press.

Ivanov, M., Tkalec, M. i Vizek, M. (2011). The determinants of financial euroization in a post-transition country: Do threshold effects matter? Czech Journal of Economics and Finance, 61(3), 230-251.

Ize, A. i Levy Yeyati, E. (2003). Financial dollarization. Journal of International Economics, 59(2), 323-347. doi: https://doi.org/10.1016/ S0022-1996(02)00017-X

Ize, A. i Powell, A. (2004). Prudential responses to de facto dollarization. IMF Working Paper No. 04/66. doi: https://doi.org/10.5089/9781451848823.001 
Izquierdo, M., Jimeno, J. F., Kosma, T., Lamo, A., Millard, S., Rõõm, T. i Viviano, E. (2017). Labor market adjustment in Europe during the crisis: Microeconomic evidence from the wage dynamics network survey. $E C B$ Occassional Papers No. 192.

Jovančević, R., Arčabić, V. i Globan, T. (2012). Prijenos poslovnih ciklusa zemalja Europske unije na Republiku Hrvatsku. Ekonomski pregled, 63(12), 3-21.

Jovičić, G. i Kunovac, D. (2017). What is driving inflation and GDP in a small European economy: The case of Croatia. Working Papers br. 49. Zagreb: Hrvatska narodna banka.

Kenen, P. (1969). The optimum currency area: An eclectic view. U R. A. Mundell i A. K. Swoboda (Ur.), Monetary problems of the international economy (str. 41-60). Chicago, IL: University of Chicago Press.

Kotarac, K., Kunovac, D. i Ravnik, R. (2017). Usklađenost poslovnih ciklusa i ekonomskih šokova između Hrvatske i država europodručja. Istraživanja HNB-a br. 51. Zagreb: Hrvatska narodna banka.

Kraft, E. (2003). Monetary policy under dollarization: The case of Croatia. Comparative Economic Studies, 45(3), 256-277. doi: https://doi. org/10.1057/palgrave.ces.8100023

Krugman, P. (1993). Lessons of Massachusetts for EMU. U F. Torres i F. Giavazzi (Ur.), Adjustment and growth in the European Monetary Union (str. 241-261). Cambridge, MA: Cambridge University Press. doi: https:// doi.org/10.1017/CBO9780511599231.016

Krugman, P. (2013). Revenge of the optimum currency area. U D. Acemoglu, J. Parker i M. Woodford (Ur.), NBER Macroeconomics Annual 2012 (str. 439-448). Chicago, IL: University of Chicago Press.

Krznar, I. (2011). Analiza kretanja domaće stope inflacije i Phillipsova krivulja. Istraživanja HNB-a br. 31. Zagreb: Hrvatska narodna banka. 
Krznar, I. i Kunovac, D. (2010). Utjecaj vanjskih šokova na domaću inflaciju i BDP. Istraživanja HNB-a br. 28. Zagreb: Hrvatska narodna banka.

Kunovac, M. i Pufnik, A. (2015). Obilježja tržišta rada i određivanja plaća u Hrvatskoj: rezultati ankete poduzeća. Pregledi HNB-a br. 27. Zagreb: Hrvatska narodna banka.

McKinnon, R. (1963). Optimum currency areas. American Economic Review, 53(4), 717-725.

Medunarodni monetarni fond. (2003). Lessons from the crisis in Argentina. Washington, DC: International Monetary Fund.

Međunarodni monetarni fond. (2006). Spain: Financial system stability assessment. IMF Country Report No. 06/212.

Mintz, N. N. (1970). Monetary union and economic integration. The Bulletin. New York, NY: New York University.

Mishkin, F. S. (1997). Understanding financial crises: A developing country perspective. NBER Working Papers No. 5600.

Mongelli, F. P. (2002). "New" views on the optimum currency area theory: What is EMU telling us? ECB Working Papers No. 138.

Mongelli, F. P. (2008). European economic and monetary integration and the optimum currency area theory. Economic Papers No. 302. Bruxelles: European Commission.

Mundell, R. A. (1961). A theory of optimum currency areas. American Economic Review, 51(4), 657-665.

Pufnik, A. i Kunovac, D. (2012). Način na koji poduzeća u Hrvatskoj određuju i mijenjaju cijene svojih proizvoda: rezultati ankete poduzeća i usporedba s eurozonom. Istraživanja HNB-a br. 39. Zagreb: Hrvatska narodna banka. 
Rey, H. (2015). Dilemma not trilemma: The global financial cycle and monetary policy independence. NBER Working Papers No. 21162. doi: https://doi.org/10.3386/w21162

Rohatinski, Ž. (2015). Ogledi u realnom vremenu (2000. - 2014.). Zagreb: EPH Media.

Stehrer, R. i Stöllinger, R. (2015). The Central European manufacturing core: What is driving regional production sharing? FIW Research Reports 2014/15 No. 2. Beč: The Vienna Institute for International Economic Studies.

Šonje, V. i Vrbanc, I. (2000). Mjerenje sličnosti gospodarskih kretanja u srednjoj Europi: povezanost poslovnih ciklusa Njemačke, Mađarske, Češke i Hrvatske. Ekonomski pregled, 51(9-10), 895-917.

Šošić, V. i Kraft, E. (2006). Floating with a large lifejacket: Monetary and exchange rate policies in Croatia under dollarization. Contemporary Economic Policy, 24(4), 492-506.

Tavlas, G. S. (1994). The theory of monetary integration. Open Economies Review, 5(2), 211-230. doi: https://doi.org/10.1007/BF01000489

Wyplosz, C. (2013). The eurozone crisis and the competitiveness legend. Asian Economic Papers, 12(3), 63-81. doi: https://doi.org/10.1162/ ASEP_a_00238 


\title{
Abstract \\ Is the Euro the Optimum Currency for Croatia: An Assessment Using the Optimum Currency Area Theory
}

\author{
PROFESSIONAL ARTICLE \\ Mislav Brkić* \\ Ana Šabić**
}

Using the optimum currency area theory, this paper analyzes whether Croatia is ready for euro adoption. The theory proposes several criteria a country should meet to be able to function successfully in a setting of common monetary policy. Most of the criteria refer to the establishment of the degree of economic integration between a country and a monetary union, in view of the fact that close economic integration implies lower risk of asymmetric shocks. The analysis shows that the Croatian economy is highly integrated with the euro area in terms of trade and finances, its business cycle is synchronized with the business cycles of the major euro area member states, while EU accession raised the degree of political integration between Croatia and other member states. Under these criteria, it may be concluded that Croatia will function efficiently in a setting of common monetary policy. By contrast, Croatia's performance regarding the economic diversification criterion is relatively poor. In addition to favorable results under most criteria of the optimum currency area theory, there are other important arguments in favor of euro adoption in Croatia. More specifically, the adoption of the euro would eliminate the problem of the high euroization of the Croatian economy, as well as a number of other risks and constraints arising from that problem. By adopting the euro, Croatia would therefore make an important step towards maintaining macroeconomic and financial stability in the long run.

Keywords: optimum currency area theory, monetary policy, euro, Croatia JEL classification: E42, E52, F33, F45

\footnotetext{
* Mislav Brkić, Croatian National Bank, e-mail: mislav.brkic@hnb.hr.

** Ana Šabić, Croatian National Bank, e-mail:ana.sabic@hnb.hr.
} 